\title{
Genetic Disorders Associated with Metal Metabolism
}

\author{
Muhammad Umair ${ }^{1}$ and Majid Alfadhel ${ }^{1,2, *(\mathbb{D}}$ \\ 1 Medical Genomics Research Department, King Abdullah International Medical Research Center (KAIMRC), \\ King Saud Bin Abdulaziz University for Health Sciences, Ministry of National Guard Health \\ Affairs (MNGH), P.O Box 3660, Riyadh 11481, Saudi Arabia; khugoo4u@yahoo.com \\ 2 Division of Genetics, Department of Pediatrics, King Abdullah Specialized Children's Hospital, \\ King Abdulaziz Medical P.O Box 22490, Riyadh 11426, Saudi Arabia \\ * Correspondence: dralfadhelm@gmail.com; Tel.: +(966)-11-805-3560; Fax: +(966)-11-805-5555
}

Received: 17 October 2019; Accepted: 5 December 2019; Published: 9 December 2019

\begin{abstract}
Genetic disorders associated with metal metabolism form a large group of disorders and mostly result from defects in the proteins/enzymes involved in nutrient metabolism and energy production. These defects can affect different metabolic pathways and cause mild to severe disorders related to metal metabolism. Some disorders have moderate to severe clinical consequences. In severe cases, these elements accumulate in different tissues and organs, particularly the brain. As they are toxic and interfere with normal biological functions, the severity of the disorder increases. However, the human body requires a very small amount of these elements, and a deficiency of or increase in these elements can cause different genetic disorders to occur. Some of the metals discussed in the present review are copper, iron, manganese, zinc, and selenium. These elements may play a key role in the pathology and physiology of the nervous system.
\end{abstract}

Keywords: metal metabolism; genetic disorders; copper; iron; manganese; zinc; selenium

\section{Introduction}

Metal ions play an important role in several biological processes that have both structural and functional importance. Human beings gain an adequate amount of nutrient metals from their daily diet, but need to avoid a toxic or an excess amount of metals for an ideal health. Both an imbalance in the amount of nutrient metals in the body and exposure to toxic metals are associated with severe health problems. They are linked to several abnormalities, including cardiovascular diseases, neurodegenerative disorders (Alzheimer's disease, Parkinson's disease, and Huntington's disease), and metabolic disorders [1-5]. The toxicity of and pathways involved in metal imbalances are now considered to be highly active areas of biomedical research. The findings of these studies might inspire us to develop new classes of therapeutic strategies and help us to understand metal metabolism $[5,6]$.

\subsection{Transfer of Groups}

"Transitional elements" or "transitional metals" are those elements that are present in the d-series (Groups 3 to 12) of the periodic table. All of the transitional or trace metals also participate in reactions that involve the transfer of specific groups. These include either phosphorylation (when a phosphate residue is transferred) or dephosphorylation (when a phosphate residue is removed). Similarly, glycosylation is the process by which a sugar residue is transferred [7].

\subsection{Neurotoxicity}

Neurotoxicity results in the accumulation of elements in the brain, such as copper, selenium, iron, and manganese, and can lead to different types of brain-associated disorders. Specific parts 
of the brain, such as the substantia nigra and the basal ganglia, are predominantly exposed to such changes. Some of the metals discussed in the present review are copper, iron, manganese, zinc, and selenium, which play a very important role in human biology. Several disorders that involve an accumulation of different metal elements in the human brain have been reported in the literature and are discussed in the present review [4,8-12]. Some disorders that are due to an accumulation of manganese, copper, or iron and cause neurotoxicity are summarized in Table 1 . The present review will highlight: (i) Disorders associated with zinc homeostasis; (ii) disorders associated with iron homeostasis; (iii) disorders associated with copper homeostasis; (iv) disorders associated with manganese homeostasis; and (v) disorders associated with selenium homeostasis.

\section{Zinc Homeostasis}

Zinc plays a very important role in the human body and acts as a cofactor for several enzymes and transcription factors that contain modules for binding DNA and RNA (zinc fingers), including alkaline phosphatase, lactate dehydrogenase, ornithine transcarbamylase, superoxide dismutase, carbonic anhydrase, DNA and RNA polymerases, matrix metalloproteinases, insulin-degrading enzymes, $\mathrm{N}$-acyl D-aspartate acylase, and alcohol dehydrogenase [13]. Zinc metalloenzymes are involved in the regulation of different metabolic pathways and have structural, catalytic, and regulatory functions [14]. Although zinc is important to proper regulation of several important physiological functions, both an excess and a deficiency of zinc have been associated with several conditions (Figure 1).

Several members of the SLC39A family encode for different zinc/iron-regulated transporter-like protein (ZIP) transporters (ZIP1-6, 8-10, 12, and 14). Their main function is the uptake of zinc at the cell surface; however, some family members also have the ability to transport manganese, iron, and cadmium [15]. Similarly, it has been reported that both SLC39A14 and SLC39A8 have similar functions and mediate manganese uptake at the cell surface [16]. Deficiencies in these ZIP transporters result in different disorders in humans (Figure 2). Many disorders have been associated with zinc deficiency; however, only a few are discussed here.

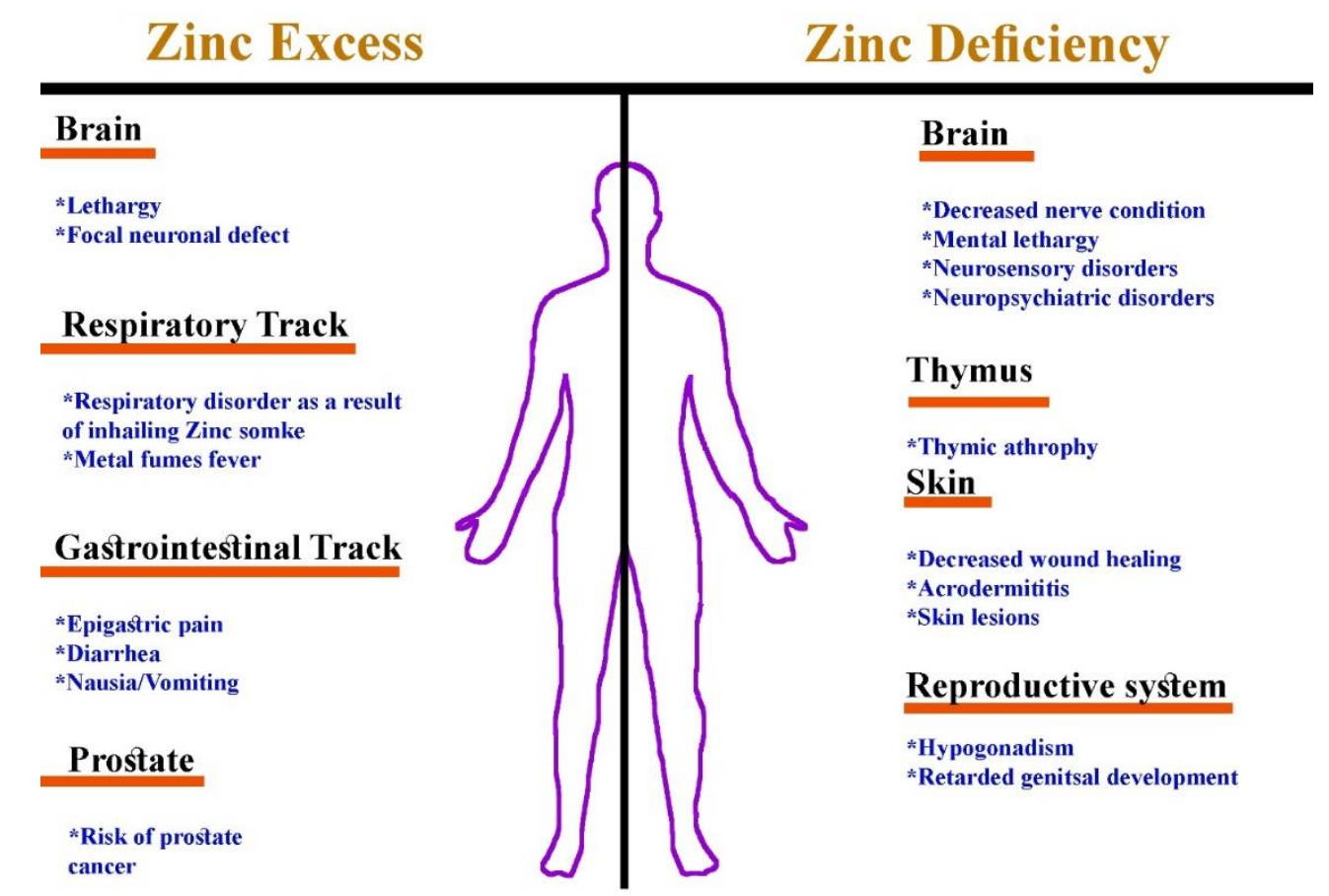

Figure 1. A schematic representation of zinc deficiency as compared to zinc intoxication. 


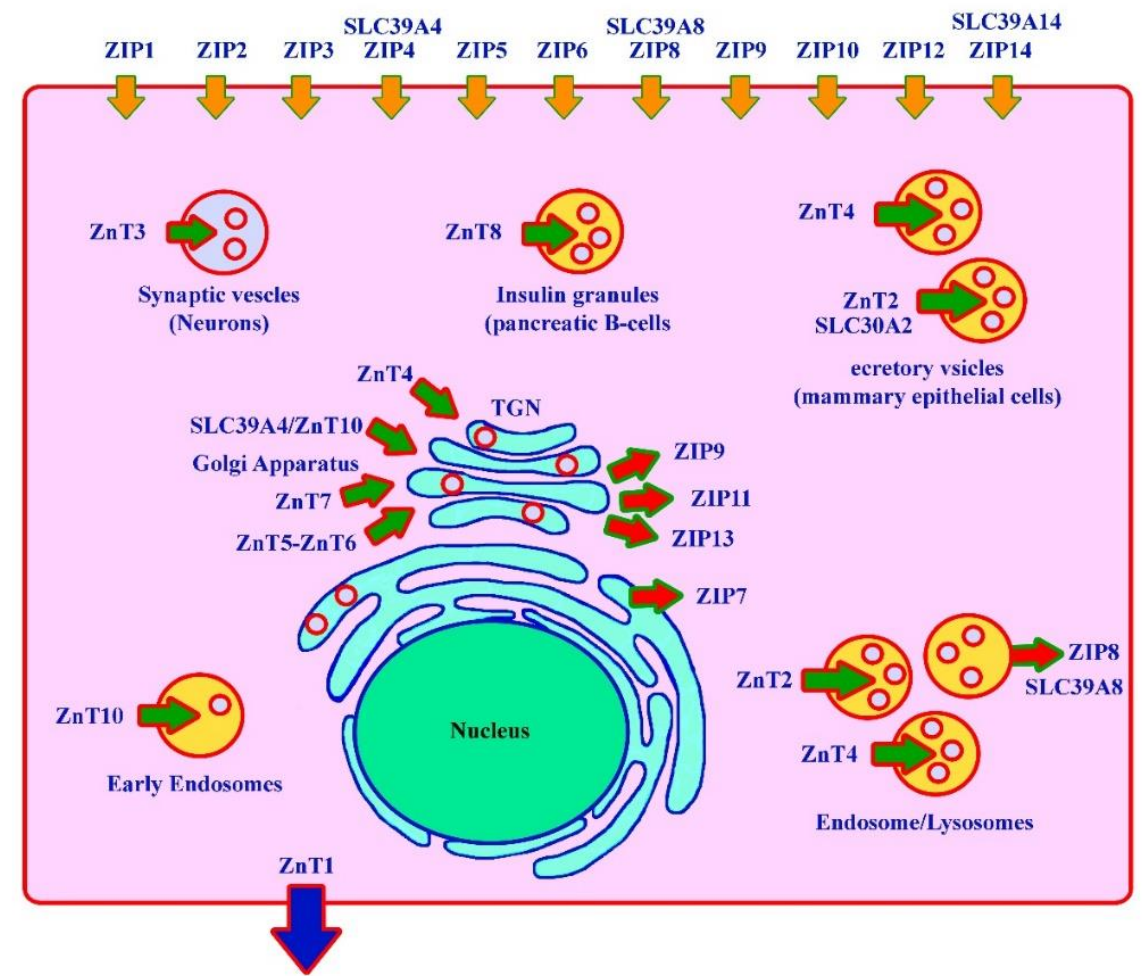

Figure 2. SLC39A family members (zinc/iron-regulated transporter-like protein (ZIP) transporters) and their role at the cellular level. Zn transporters belong to the SLC30A family. These cause different disorders in humans. 
Table 1. Disorders that are due to an accumulation of manganese, copper, or iron and cause neurotoxicity.

\begin{tabular}{|c|c|c|c|c|c|c|}
\hline Disorders & Transition Metal & Inheritance & Gene & OMIM & Gene Function & Symptoms \\
\hline Hypermanganesemia with dystonia 1 & Manganese & $\begin{array}{l}\text { Autosomal } \\
\text { recessive }\end{array}$ & SLC30A10 & 613280 & Manganese transporter & $\begin{array}{l}\text { Dystonia, cock-walk gait } \\
\text { Parkinsonism }\end{array}$ \\
\hline Hypermanganesemia with dystonia 2 & Manganese & $\begin{array}{l}\text { Autosomal } \\
\text { recessive }\end{array}$ & SLC39A14 & 617013 & Manganese transporter & $\begin{array}{l}\text { Progressive dystonia and bulbar } \\
\text { dysfunction }\end{array}$ \\
\hline Wilson's disease & Copper & $\begin{array}{l}\text { Autosomal } \\
\text { recessive }\end{array}$ & АТР7B & 277900 & Copper transporter & $\begin{array}{l}\text { Dysarthria, dysphagia, } \\
\text { tremor, dystonic rigidity }\end{array}$ \\
\hline $\begin{array}{l}\text { Acaeruloplasminaemia, Cerebellar ataxia, } \\
\text { Hypoceruloplasminemia }\end{array}$ & Iron & $\begin{array}{l}\text { Autosomal } \\
\text { recessive }\end{array}$ & $C P$ & 604290 & Ferroxidase & $\begin{array}{l}\text { Chorea, ataxia, dystonia, } \\
\text { Parkinsonism, Diabetes mellitus }\end{array}$ \\
\hline $\begin{array}{l}\text { Neuroferritinopathy, } \\
\text { Hyperferritinemia-cataract syndrome, } \\
\text { L-ferritin deficiency }\end{array}$ & Iron & $\begin{array}{c}\text { Autosomal } \\
\text { dominant }\end{array}$ & FTL & $\begin{array}{l}600886 \\
615604 \\
606159\end{array}$ & Iron storage & Chorea, dystonia \\
\hline Spastic paraplegia type 35 & Iron & $\begin{array}{l}\text { Autosomal } \\
\text { recessive }\end{array}$ & $F A 2 H$ & 612319 & $\begin{array}{l}\text { Fatty acid 2-hydroxylase } \\
\text { (Synthesis of sphingolipids) }\end{array}$ & $\begin{array}{c}\text { Gait difficulties with } \\
\text { spastic paraparesis and dysmetria }\end{array}$ \\
\hline $\begin{array}{l}\text { Neurodegeneration with brain iron } \\
\text { accumulation } 1 \text {, HARP syndrome }\end{array}$ & Iron & $\begin{array}{l}\text { Autosomal } \\
\text { recessive }\end{array}$ & PANK2 & $\begin{array}{l}607236 \\
234200\end{array}$ & $\begin{array}{l}\text { Pantothenate kinase } \\
\text { (CoA synthesis) }\end{array}$ & $\begin{array}{l}\text { Dystonia, rigidity, } \\
\text { choreoathetosis }\end{array}$ \\
\hline $\begin{array}{l}\text { Neurodegeneration with brain iron } \\
\text { accumulation 6, Pontocerebellar hypoplasia } \\
\text { type } 12\end{array}$ & Iron & $\begin{array}{l}\text { Autosomal } \\
\text { recessive }\end{array}$ & COASY & $\begin{array}{l}615643 \\
618266\end{array}$ & CoA synthesis & $\begin{array}{l}\text { Dystonia, rigidity, } \\
\text { choreoathetosis }\end{array}$ \\
\hline $\begin{array}{c}\text { Infantile neuroaxonal dystrophy } 1, \\
\text { Neurodegeneration with brain iron } \\
\text { accumulation 2B, Parkinson's disease type } \\
14\end{array}$ & Iron & $\begin{array}{l}\text { Autosomal } \\
\text { recessive }\end{array}$ & PLA2G6 & $\begin{array}{l}256600 \\
610217 \\
612953\end{array}$ & Phospholipase & Motor regression, hypotonia \\
\hline $\begin{array}{l}\text { Spastic paraplegia } 43 \text {, Neurodegeneration } \\
\text { with brain iron accumulation } 4\end{array}$ & Iron & $\begin{array}{l}\text { Autosomal } \\
\text { recessive }\end{array}$ & C19orf12 & $\begin{array}{l}615043 \\
614298\end{array}$ & $\begin{array}{l}\text { Mitochondrial } \\
\text { magnesium } \\
\text { homeostasis }\end{array}$ & $\begin{array}{l}\text { Spastic paraplegia, } \\
\text { Parkinsonism }\end{array}$ \\
\hline $\begin{array}{l}\text { Woodhouse-Sakati } \\
\text { syndrome }\end{array}$ & Iron & $\begin{array}{l}\text { Autosomal } \\
\text { recessive }\end{array}$ & DCAF17 & 241080 & Ubiquitinylation & $\begin{array}{l}\text { Developmental delay } \\
\text { Dystonia, dysarthria, } \\
\text { choreoathetosis }\end{array}$ \\
\hline $\begin{array}{l}\text { Neurodegeneration with brain iron } \\
\text { accumulation type } 5\end{array}$ & Iron & $\begin{array}{l}\text { X-linked } \\
\text { dominant }\end{array}$ & WDR45 & 300894 & Autophagy & $\begin{array}{l}\text { Global developmental } \\
\text { Delay, Delayed psychomotor } \\
\text { development, Mental retardation, Poor } \\
\text { speech, Lack of speech }\end{array}$ \\
\hline $\begin{array}{c}\text { Kufor-Rakeb syndrome, Spastic paraplegia } \\
\text { type } 78\end{array}$ & Iron & $\begin{array}{l}\text { Autosomal } \\
\text { recessive }\end{array}$ & ATP13A2 & $\begin{array}{l}606693 \\
617225\end{array}$ & $\begin{array}{l}\text { Lysosomal divalent cation } \\
\text { (transition metal) transporter }\end{array}$ & $\begin{array}{c}\text { Atypical Parkinsonism } \\
\text { Supranuclear gaze palsy } \\
\text { Spasticity }\end{array}$ \\
\hline
\end{tabular}




\subsection{Disorders Associated with Zinc Homeostasis}

\subsubsection{Acrodermatitis Enteropathica}

Acrodermatitis enteropathica (OMIM 201100) is an autosomal recessive disorder caused by biallelic sequence variants in the SLC39A4 gene (OMIM 607059) located on chromosome 8q24. The SLC39A4 (Solute Carrier Family 39 Member 4) gene encodes for ZIP4, which belongs to the zinc/iron-regulated transporter-like protein (ZIP) family. The clinical description includes short stature, failure to thrive, hepatomegaly (liver), decreased intestinal uptake of zinc, diarrhea, poor appetite, bullous pemphigoid, pustular dermatitis on extremities, necrosis with inflammation, alopecia, cerebellar ataxia, decreased testosterone in males, and a decrease in plasma zinc, serum alkaline phosphatase, and mucosal alkaline phosphatase levels [4,17-20]. To date, only 52 disease-causing mutations associated with acrodermatitis enteropathica have been reported in the SLC39A4 gene (HGMD, 2018; http://www.hgmd.cf.ac.uk).

\subsubsection{Transient Neonatal Zinc Deficiency}

Transient neonatal zinc deficiency (OMIM 608118) is an autosomal dominant disorder caused by heterozygous or de novo sequence variants in the SLC30A2 gene (OMIM 609617) located on chromosome 1p36.11. The SLC30A2 (Solute carrier family 30 member 2) gene encodes for ZNT2, which is a zinc transporter that acts as a homodimer in mammary epithelial cells. This disorder leads to low zinc concentrations in maternal milk and the infant might show clinical phenotypic similarity to acrodermatitis enteropathica, including dermatitis and partial alopecia [21-23]. To date, only 28 disease-causing mutations associated with zinc deficiency in breast milk have been reported in the SLC30A2 gene (HGMD, 2018; http://www.hgmd.cf.ac.uk).

\subsubsection{Ehlers-Danlos Syndrome (Spondylodysplastic Type 3: SCD-EDS)}

Biallelic mutations in the SLC39A13 gene (OMIM 608735) located on chromosome 11p11.2, which encodes for the zinc transporter ZIP13, causes severe SCD-EDS (OMIM 612350). It is characterized by an EDS-like phenotype, including short stature, protuberant eyes, bifid uvula, a high palate, hypodontia, delayed teeth eruption, muscle atrophy, platyspondyly, osteopenia, joint laxity, flat feet, irregular vertebral bodies, and other skeletal manifestations [24].

Usually, the serum zinc levels are normal but the intracellular zinc distribution is abnormal, leading to an abnormal nuclear translocation of SMADs. This results in alterations in BMP and TGF $\beta$ signaling in collagen-producing cells [25].

\subsubsection{Birk-Landau-Perez Syndrome}

Birk-Landau-Perez syndrome is an autosomal recessive condition caused by homozygous mutations in the SLC30A9 gene located on chromosome 4p13. The SLC30A9 (Solute carrier family 30 member 9) gene encodes for the 586 amino-acid-long ZnT9 (Zinc transporter 9) protein. ZnT9 is localized in the endoplasmic reticulum (ER), and a ZnT9 shortage leads to interrupted zinc homeostasis and a decrease in zinc cytosolic concentrations. The clinical characterization includes oculomotor apraxia, abnormal eye movements, ptosis, renal dysfunction, hyperechogenic kidneys, axial hypotonia, cognitive impairment, dyskinesia, choreoathetosis, dystonia, and hyperkalemia [26]. To date, only a single Arab family from Bedouin has been reported as having Birk-Landau-Perez syndrome. Using genome-wide homozygosity mapping and whole exome sequencing, Perez et al. (26) reported a frame shift variant (c.1047_1049delGCA; p.A350del) in the SLC30A9 gene.

\section{Iron Homeostasis}

In humans, iron is absorbed through the intestinal tract and excreted through the urine and the bile. In healthy adults, the normal iron pool ranges from 2 to $6 \mathrm{~g}, 0.5 \mathrm{~g}$ of which is usually stored in the liver, and includes $98 \%$ hepatocytes $[27,28]$. Iron absorption requires specific transporters that are 
located in the basolateral and apical membranes of the intestinal mucosal cells. Ferroportin, which is a basolateral transporter, can bind to the hepcidin protein, which inactivates the ferroportin and restricts iron absorption in the mucosal cells. High transferrin saturation results in the release of hepcidin in the liver in response, which inhibits iron release from macrophages. Whenever the absorption of iron is excessive, it results in an iron overload [29].

Transcription of hepcidin results from an increase in the iron level in plasma, which has major effects on such target cells as macrophages and principally enterocytes (Figure 3). In both of these cells, an increase in hepcidin causes the degradation of ferroportin, which exports iron from the cell. The increase in hepcidin will affect macrophages, resulting in a reduced amount of iron being released into the plasma. To bring the amount of iron back into a normal range, the net amount of iron in the plasma needs to be reduced $[28,29]$.

Iron from the plasma is taken up by cells only if the hepcidin pathway is impaired. These cells include those of the pancreas, liver, heart, and several other organs that may cause diabetes, cirrhosis, and cardiomyopathy. Hepcidin levels can also be triggered in the case of inflammation and infection until the amount of iron in the plasma returns to normal, which leads to a low amount of iron being observed in the plasma during chronic infection/inflammation [29]. Mutations in genes responsible for causing genetic haemachromatosis are listed in Table 2. These include HAMP, HFE1, HJV, HAMP, TRF2, and SLC40A1.

Table 2. Disorders associated with iron metabolism leading to hepcidin deficiency.

\begin{tabular}{|c|c|c|c|c|c|c|}
\hline S. No. & Gene & Inheritance & Protein & $\begin{array}{c}\text { Role in Fe } \\
\text { Metabolism }\end{array}$ & Anaemia & Treatment \\
\hline 1 & $\begin{array}{l}\text { HAMP } \\
(606464)\end{array}$ & $\begin{array}{l}\text { Autosomal } \\
\text { recessive }\end{array}$ & Hepcidin & $\begin{array}{l}\text { Inhibits iron release } \\
\text { by ferroportin }\end{array}$ & - & Not Available \\
\hline 2 & $\begin{array}{c}\text { HFE1 } \\
(235200)\end{array}$ & $\begin{array}{l}\text { Autosomal } \\
\text { recessive }\end{array}$ & HFE & $\begin{array}{l}\text { Regulates synthesis } \\
\text { of hepcidin }\end{array}$ & - & $\begin{array}{l}\text { Phlebotomy for ferritin } \\
>1000 \mathrm{ng} / \mathrm{mL}\end{array}$ \\
\hline 3 & $\begin{array}{c}H J V \\
(608374)\end{array}$ & $\begin{array}{l}\text { Autosomal } \\
\text { recessive }\end{array}$ & Haemojuvelin & $\begin{array}{l}\text { Regulates synthesis } \\
\text { of hepcidin }\end{array}$ & - & $\begin{array}{c}\text { Phlebotomy effective if } \\
\text { started early }\end{array}$ \\
\hline 4 & $\begin{array}{c}\text { TRF2 } \\
(602027)\end{array}$ & $\begin{array}{l}\text { Autosomal } \\
\text { recessive }\end{array}$ & $\begin{array}{l}\text { Transferrin } \\
\text { receptor } 2\end{array}$ & $\begin{array}{l}\text { Regulates synthesis } \\
\text { of hepcidin }\end{array}$ & - & Phlebotomy \\
\hline \multirow{2}{*}{5} & \multirow{2}{*}{$\begin{array}{r}S L C 30 A 1 \\
(603653)\end{array}$} & \multirow{2}{*}{$\begin{array}{l}\text { Autosomal } \\
\text { dominant }\end{array}$} & $\begin{array}{l}\text { Ferroportin (loss of } \\
\text { function) }\end{array}$ & \multirow{2}{*}{$\begin{array}{l}\text { Export from cells into } \\
\text { circulation }\end{array}$} & \multirow{2}{*}{$\begin{array}{l}\text { Mild } \\
\text { microcytic }\end{array}$} & \multirow{2}{*}{ Phlebotomy } \\
\hline & & & $\begin{array}{l}\text { Ferroportin (gain in } \\
\text { hepcidin resistance) }\end{array}$ & & & \\
\hline
\end{tabular}

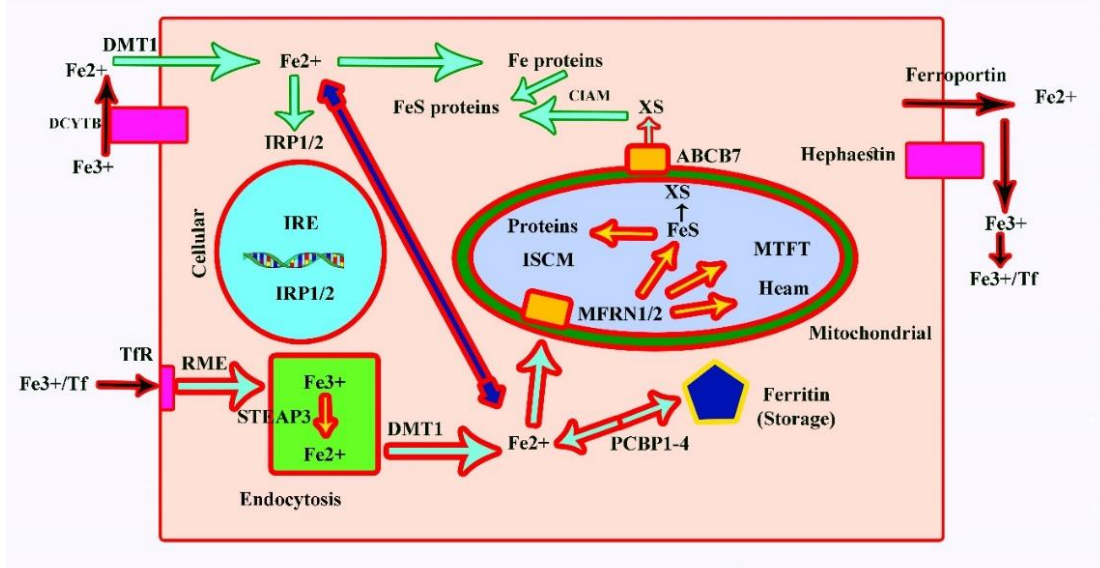

Figure 3. Iron metabolism at the cellular level and its regulation. TfR: Transferrin receptor; IRE: Iron-responsive element; RME: Receptor-mediated endocytosis; E: Endosome; ISCM: Iron-sulphur cluster machinery; Ff: Transferrin; IRP: Iron-responsive protein; FeS: Iron-sulphur cluster; XS: Unknown sulphur transporter; CIAM: Cytosolic iron-sulphur cluster assembly machinery; PCBP: Poly (rC) binding protein. 


\subsection{Cellular Processing of Iron and Its Regulation}

Iron (Fe2+) uptake at the surface of cells occurs with the help of DMT1, which encodes a divalent metal transporter that also helps uptake into enterocytes. As a result, the Fe3+-bound transferrin binds the transferrin receptor at the surface of the cell and results in endocytosis [17,30]; Figure 3).

First, the uptake (by endocytotic vesicles) requires the conversion of $\mathrm{Fe} 3+$ to $\mathrm{Fe} 2+$, which is done by the endosomal ferrireductase STEAP3 followed by DMT1. Mitoferrin 1 (MFRN1; SLC25A37) and mitoferrin 2 (MFRN2; SLC25A28) are required to transport iron into the mitochondria. Mitochondrial $\mathrm{Fe} 2+$ has two principal destinies, including synthesis of iron-sulphur clusters and synthesis of haem. Within mitochondria, iron is normally stored as mitochondrial ferritin (MTFT). Cytosolic Fe can be converted into FeS proteins and Fe proteins with the help of the PCB1-4-dependent pathway into ferritin $[17,30]$.

Proper regulation of the iron homeostasis in the cytosole comprises binding of iron to iron-responsive proteins $1 / 2$ (IRP1/2), which are also designated as iron-responsive element binding proteins (IREB1/2). These IRPs bind to IREs and control transcription of the iron-responsive proteins. The inability of the cell to use iron for haem group synthesis leads to the form of iron deficiency known as anaemia and can cause an overload of iron in the liver. The disorders that result due to iron overload are listed in Table $3[31,32]$.

\subsection{Iron Homeostasis and Related Disorders}

\subsubsection{Ferroportin Disease}

Pathogenic heterozygous mutations in the SLC40A1 gene (OMIM 604653) cause hemochromatosis type 4 (OMIM 606069). SLC40A1 encodes for ferroportin located on chromosome 2q32.2, which is the only known iron exporter in mammals. SLC40A1 loss-of-function (LOF) mutations lead to the classical type A ferroportin disease, which is characterized by such features as cataracts, cardiomyopathy, fibrosis, joint pains, osteoarthritis, hyperpigmentation, endocrine disorders, and anemia [33,34].

\subsubsection{Hereditary Hemochromatosis}

Parenchymal cells in the liver and pancreas store most of the body's iron, and an excessive accumulation of iron may lead to hemochromatosis [35]. In this condition, the total amount of accumulated iron exceeds more than $50 \mathrm{~g}$ in the body. This accumulation of iron is life long and usually takes five to six decades to show symptoms [36,37]. Mutations have been reported in five different genes associated with hemochromatosis, including HJV (HFE) and HAMP. Both are responsible for causing hemochromatosis type 2, also known as juvenile hemochromatosis (OMIM 602390), which results in severe iron overload at $<30$ years of age. Mutations in the TFR2 gene cause hemochromatosis type 3 (OMIM 604250), and FTH1 heterozygous mutations result in hemochromatosis type 5 (OMIM 615517).

All of these gene products function in pathways that are involved in the production of hepcidin in the hepatocytes. Thus, a lack of proper hepcidin production results in disrupted regulation of iron absorption in the intestinal track.

\subsubsection{Neurodegeneration with Iron Accumulation in the Brain (NBIA)}

In the literature, several inborn brain iron accumulation disorders have been reported [38]. NBIA comprises a group of neurodegenerative diseases that are mostly characterized by excessive iron accumulation in different parts of the central nervous system (CNS), particularly in the basal ganglia $[38,39]$. The two most common types that result due to iron homeostasis are discussed here. A list of genes involved in NBIA is presented in Table 3. 
Table 3. A list of genes involved in neurodegeneration with iron accumulation in the brain (NBIA).

\begin{tabular}{|c|c|c|c|c|c|c|c|}
\hline S. No. & $\begin{array}{c}\text { Gene } \\
\text { (OMIM) }\end{array}$ & Inheritance & Protein & $\begin{array}{l}\text { Disorder } \\
\text { (OMIM) }\end{array}$ & $\begin{array}{c}\text { Role in Fe } \\
\text { Metabolism }\end{array}$ & Other & Treatment \\
\hline 1 & $\begin{array}{l}\text { SLC11A2 } \\
(600523)\end{array}$ & $\begin{array}{l}\text { Autosomal } \\
\text { recessive }\end{array}$ & DMT1 & $\begin{array}{c}\text { Anemia, } \\
\text { hypochromic } \\
\text { microcytics } \\
\text { with iron } \\
\text { overload } 1 \\
(206,100)\end{array}$ & $\begin{array}{l}\text { Duodenal uptake } \\
\text { Intracellular } \\
\text { release }\end{array}$ & $\begin{array}{c}\text { Increased } \mathrm{Cu} \text { in brain } \\
\text { associated with } \\
\text { impulsivity in a rat } \\
\text { model }\end{array}$ & $\begin{array}{l}\text { Erythropoietin } \\
\text { (EPO) }\end{array}$ \\
\hline 2 & $\begin{array}{l}\text { TMPRSS6 } \\
(609862)\end{array}$ & $\begin{array}{l}\text { Autosomal } \\
\text { recessive }\end{array}$ & Matriptase 2 & $\begin{array}{l}\text { Iron-refractory, } \\
\text { iron deficiency } \\
\text { anemia } \\
(206,200)\end{array}$ & $\begin{array}{l}\text { Mutations lead to } \\
\text { high hepcidin } \\
\text { levels }\end{array}$ & - & - \\
\hline 3 & $\begin{array}{l}\text { STEAP3 } \\
(609671)\end{array}$ & $\begin{array}{l}\text { Autosomal } \\
\text { dominant }\end{array}$ & STEAP3 & $\begin{array}{c}\text { Anemia, } \\
\text { hypochromic } \\
\text { microcytics } \\
\text { with iron } \\
\text { overload } 2 \\
(615,234)\end{array}$ & $\begin{array}{l}\text { For cytoplasmic } \\
\text { uptake } \\
\text { endosomal } \\
\text { ferrireductase is } \\
\text { required }\end{array}$ & $\begin{array}{c}\text { Hepatosplenomegaly } \\
\text { Hypopituitarism } \\
\text { Hypogonadism }\end{array}$ & $\begin{array}{l}\text { Transfusion } \\
\text { Fe chelation }\end{array}$ \\
\hline 4 & $\begin{array}{c}\text { TFRC } \\
(190010)\end{array}$ & $\begin{array}{l}\text { Autosomal } \\
\text { recessive }\end{array}$ & $\begin{array}{l}\text { Transferrin } \\
\text { receptor } 1\end{array}$ & $\begin{array}{l}\text { Immunodeficiency } \\
46(616,740)\end{array}$ & ${ }^{y}$ Cellular uptake & $\begin{array}{c}\text { Combined } \\
\text { immunodeficiency } \\
\text { Leukopenia } \\
\text { Thrombocytopenia }\end{array}$ & - \\
\hline 5 & $\begin{array}{c}\text { TF } \\
(190000)\end{array}$ & $\begin{array}{l}\text { Autosomal } \\
\text { recessive }\end{array}$ & Transferrin & $\begin{array}{l}\text { Atransferrinemia } \\
(209,300)\end{array}$ & $\begin{array}{l}\text { Fe transport in } \\
\text { blood, uptake }\end{array}$ & $\begin{array}{l}\text { Growth retardation } \\
(\mathrm{TF}<20 \mathrm{mg} / \mathrm{dL})\end{array}$ & $\begin{array}{l}\text { Plasma } \\
\text { infusions }\end{array}$ \\
\hline
\end{tabular}

\subsubsection{Acaeruloplasminaemia}

Homozygous variants in the $C P$ gene cause unnoticeable levels of caeruloplasmin in the plasma. Affected individuals have excess iron accumulated in the islets of the Langerhans (liver) and the brain. Affected individuals suffer from neurological symptoms (ataxia, chorea, dystonia, psychiatric disorders, and Parkinsonism), diabetes mellitus, and retinal degeneration. Ferrous ( $\mathrm{Fe} 2+)$ iron is converted into ferric (Fe3+) iron in the plasma by an enzyme called caeruloplasmin, which is a copper-containing enzyme secreted by the liver. Affected individuals suffering from acaeruloplasminaemia have high serumferritin and low serum iron levels [40,41]. To date, only 60 disease-causing mutations associated with acaeruloplasminaemia and Parkinsonism-related disorders have been reported in the $C P$ gene (HGMD, 2018; http://www.hgmd.cf.ac.uk).

\subsubsection{Neuroferritinopathy}

Heterozygous variants in the FTL gene (OMIM 134790) cause hyperferritinemia cataract syndrome (OMIM 60886) and neurodegeneration with brain iron accumulation type 3 (OMIM 606159). Associated clinical phenotypes include blepharospasm, palatal tremor, dystonia, micrographia, dysphagia, gait disability, tremor, Parkinsonism, choreoathetosis, and hyper-reflexia [42,43]. To date, only 64 disease-causing mutations associated with hyperferritinemia cataract syndrome have been reported in the FTL gene (HGMD, 2018; http://www.hgmd.cf.ac.uk).

\section{Copper Homeostasis}

Approximately $100 \mathrm{mg}$ of copper is stored in the human body, of which $35 \mathrm{mg}$ is contained in muscles, $10 \mathrm{mg}$ is contained in connective tissues, $20 \mathrm{mg}$ is contained in the brain, $10 \mathrm{mg}$ is contained in the blood, and $5 \mathrm{mg}$ is contained in the kidneys [44,45]. Approximately $1-5 \mathrm{mg}$ of copper is excreted from and absorbed into the human body daily, such that the net balance is zero (Table 4). Copper in the plasma, which accounts for $90 \%-95 \%$, is bound to an alpha-glycoprotein ceruloplasmin, and the binding process is completed in the liver once it is hepatically taken up. Different copper-containing enzymes are listed in Table 5, which also includes dopamine hydroxylase and tyrosine hydroxylase. These two produce neurotransmitters in the CNS. The list also includes an enzyme cytochrome $c$ oxidase, which is very important to mitochondrial energy production, electron transport, and proteins 
related to ceruloplasmin, a blue-colored plasma protein that binds up to $95 \%$ of circulating copper and plays a key role in the regulation of iron homeostasis [46-48].

Table 4. The copper balance in the body $[4,44,45]$.

\begin{tabular}{ccccc}
\hline S. No. & Copper Amount & Wilson Disease & Normal & Menkes Disease \\
\hline 1 & Copper dietary intake (mg/day) & 5 & 5 & 5 \\
2 & Copper intestinal absorption (mg/day) & 2 & 2 & $0.1-0.2$ \\
3 & Copper biliary excretion (mg/day) & $0.2-0.4$ & 2 & - \\
4 & Copper urinary excretion (ug/day) & $100-1000$ & $15-60$ & increased \\
5 & Copper balance & Positive & 0 & Negative \\
6 & Serum copper (mg/L) & $0.19-0.63$ & $0.75-1.45$ & $<0.70$ \\
7 & Serum ceruloplasmin (mg/L) & $0-200$ & $180-360$ & $<50$ \\
8 & Liver copper (ug/g dry weight) & $200-3000$ & $70-140$ & $10-20$ \\
9 & Duodenal copper (ug/g dry weight) & - & $7-29$ & $50-80$ \\
\hline
\end{tabular}

Table 5. List of enzymes containing copper.

\begin{tabular}{|c|c|c|c|}
\hline S. No. & Enzyme & Function & Deficiency \\
\hline 1 & Sulfhydryl oxidase & Cross-linking of keratin & Pili torti \\
\hline 2 & Diamine oxidases & Degrade histamine & Histamine response increased \\
\hline 3 & Superoxide dismutase & Free radical detoxification & $\begin{array}{l}\text { Protection against oxygen } \\
\text { free radicals decreased }\end{array}$ \\
\hline 4 & $\begin{array}{l}\text { Peptidylglycine-aminating } \\
\text { monoxygenase }\end{array}$ & $\begin{array}{l}\text { Removes carboxy-terminal glycine to } \\
\text { activate neuroendocrine peptides }\end{array}$ & $\begin{array}{l}\text { Reduced activity of gastrin, } \\
\text { cholecystokinin }\end{array}$ \\
\hline 5 & Lysyl oxidase & Cross-linking of collagen and elastin & $\begin{array}{l}\text { Arterial abnormalities; bladder } \\
\text { diverticulae; lax skin and joints }\end{array}$ \\
\hline 6 & Dopamine- $\beta$-hydroxylase & $\begin{array}{l}\text { Dopamine production in neurons } \\
\text { Catecholamine production }\end{array}$ & $\begin{array}{l}\text { Reduced number of neurotransmitters, } \\
\text { Neurologic effects; temperature instability; } \\
\text { pupillary constriction }\end{array}$ \\
\hline 7 & Tyrosinase & Melanin production in skin & Reduced pigmentation \\
\hline 8 & Cytochrome c oxidase & Electron transport chain & $\begin{array}{l}\text { Decreased energy in muscle and neurons; } \\
\text { impaired myelination; }\end{array}$ \\
\hline 9 & Ascorbate oxidase & Dehydroascorbate production & Skeletal demineralization \\
\hline 10 & Ceruloplasmin & $\begin{array}{l}\mathrm{Fe}(\mathrm{II}) / \mathrm{Fe}(\mathrm{III}) \text { oxidation and may be } \\
\text { involved in lipid peroxidation }\end{array}$ & $\begin{array}{c}\text { Aceruloplasminemia, Cerebellar ataxia, } \\
\text { Hemosiderosis }\end{array}$ \\
\hline 11 & Hephaestin & Intestinal iron efflux & $\begin{array}{l}\text { Hemochromatosis Type } 1 \text { Deficiency, } \\
\text { Anemia }\end{array}$ \\
\hline 12 & Zyklopen & Placental iron efflux & $\begin{array}{l}\text { Abnormal hair, joint laxity, and } \\
\text { developmental delay }\end{array}$ \\
\hline
\end{tabular}

\subsection{Disorders Associated with Copper Homeostasis}

\subsubsection{Wilson Disease}

Wilson disease (OMIM 277900) is an autosomal recessive inherited disorder characterized by buildup of intracellular hepatic copper with severe neurological and hepatic abnormalities. It is caused by biallelic mutations in the ATP7B gene (OMIM 606882) located on chromosome 13q14 and encodes a cation-transporting, P-type adenosine triphosphatase (ATPase). Associated clinical features include a Kayser-Fleischer ring, hepatic cirrhosis, comma, liver failure, hepatocellular carcinoma, renal tubular dysfunction, renal calculi, osteoporosis, osteoarthritis, joint hypermobility, dysphagia, dementia, dystonia, and tremors [49].

The disease has a prevalence of 10/3000 live births and the heterozygote-carrier state has a prevalence of slightly higher than $1 / 100$. Wilson disease is very common in consanguineous populations, such as certain isolated communities in Sardinia, Japan, and the Middle East. Although heterozygous individuals are phenotypically normal, approximately $20 \%$ have low serum copper and ceruloplasmin levels [50-55]. 
More than 700 mutations causing Wilson disease have been reported in the ATP7B gene, and almost half of these are missense mutations (H1069Q, most common) [56]; HGMD, 2018). The protein that is encoded by the $A T P 7 B$ gene functions in the trans-Golgi region of hepatocytes and transports copper into the secretory system. A homozygous mutation in the ATP7A gene results in a failure to uptake copper, resulting in a cellular copper deficiency. This copper deficiency gives rise to three main phenotypes: Menkes disease, X-linked distal neuropathy, and occipital horn syndrome [57]. Mutations that lead to improper copper excretion result in copper toxicity, which leads to Wilson disease and affects the liver and central nervous system.

Neurological Presentation in Wilson Disease

Individuals affected with Wilson disease manifest neurological symptoms within 8-20 years of age. Patients also have a movement disorder, such as dysarthria, dysgraphia, tremor (progressive), drooling, and dystonics. MRI and a CT scan are typically used to visualize the changes in the striatum; however, patients show different densities due to clinical heterogeneity [58]. The phenotype can become severe while under treatment, with only $34 \%$ of patients showing improvement in these symptoms. It has been reported that $35 \%$ of patients treated with D-penicillamine and $19 \%$ treated with zinc sulphate suffered from worse neurological symptoms $[59,60]$. However, neurological deterioration was reported in $27 \%$ of affected individuals treated with trientine [54,55]. Further research is required to find an appropriate drug to treat such a severe neurological disorder.

Liver Failure Associated with Wilson Disease

Liver failure is a life-threatening issue for patients with Wilson's disease, and, currently, if the severity score (SS) is 11, the only treatment is liver transplantation [61]. This is very difficult to accomplish due to donor organ availability and matching. It has been reported that, in an ATP7B-deficient rat, methanobactin treatment reversed acute liver failure. Methanobactin is reported to have a high affinity to copper and to be more efficient in extracting copper in Atp $7 b^{-1-}$ knockout rats [62].

\subsubsection{MEDNIK Syndrome}

MEDNIK syndrome (OMIM 609313) is caused by mutations in the AP1S1 gene (OMIM 603531) located on chromosome 7q22.1. The AP1S1 gene encodes adaptor protein complex 1 subunit $\beta 1$, which is necessary for the trafficking of ATP7 (A and B) out of the trans-Golgi network (TGN). The clinical phenotype associated with MEDNIK syndrome includes enteropathy, mental retardation, deafness, keratoderma, peripheral neuropathy, brain atrophy, ichthyosis, and cholestatic hepatopathy [63]. In this disorder, the caeruloplasmin and copper concentrations are elevated in the liver and reduced in the plasma $[63,64]$. To date, only three disease-causing mutations associated with AP1S1-related MEDNIK syndrome have been reported in the literature (HGMD, 2018; http://www.hgmd.cf.ac.uk).

\subsubsection{Menkes Disease}

Menkes disease (OMIM 309400) is a copper deficiency disorder inherited in an X-linked recessive fashion and mutations in the ATP7A gene (OMIM 300011) have been associated with this disorder. ATP7A (ATPase Copper Transporting Alpha) is a protein-coding gene located on chromosome Xq21.1. The clinical features associated with Menkes disease include microcephaly, short stature, intracranial hemorrhage, osteoporosis, skin hypopigmentation, hypotonia, mental retardation, seizures, and low copper and ceruloplasmin levels upon laboratory analysis. To date, more than 350 mutations responsible for Menkes disease in the ATP7A gene have been reported (HGMD, 2018; http://www.hgmd.cf.ac.uk). It is characterized by the proper transport of copper into copper-containing enzymes, which results in low ceruloplasmin and copper serum levels [65-69]. The incidence of Menkes disease is approximately 10/25,000 live births [67]. 


\subsubsection{Occipital Horn Syndrome (OHS)}

OHS is an X-linked recessive disorder characterized by cutis laxa, coarse hair, cerebral calcification exostoses, hyperextensible skin, mild cognitive deficits, global developmental delay, and loose joints. This condition might affect copper levels in the body and is regarded as a mild form of Menkes disease. OHS is caused by pathogenic disease-causing mutations in the ATP7A gene (OMIM 300489) [70-72]. The ATP7A gene encodes a P-type ATPase whose function is to transport copper across membranes. The ATP7A protein is mostly localized in the trans Golgi, where it helps to supply copper to different enzymes that are copper-dependent in the secretory pathway [72,73].

\subsubsection{Huppke-Brendel Syndrome (HBS)}

HBS is a recessive disorder characterized by bilateral congenital cataracts, developmental delay, cerebral atrophy, hypacusis, hearing loss, and nystagmus. MRI of the brain reveals cerebellar hypoplasia, hypomyelination, and wide subarachnoid spaces. To date, only a few patients have been reported as having low serum copper and ceruloplasmin levels [74,75]. It is caused by homozygous or compound heterozygous mutations in the SLC33A1 gene (OMIM 603690) located on chromosome 3q25.31.

\subsubsection{X-Linked Distal Hereditary Motor Neuropathy}

Distal Hereditary Motor Neuropathy is a rare X-linked disorder characterized by such features as progressive weakness of distal muscles, motor neuron syndrome, affected peripheral nerves, muscle atrophy, and an abnormal sensory examination [76]. Genetic analysis revealed a maximum LOD score of 3.46 at Xq13.1-q21, flanked by markers DXS8052 and DXS559. Sequencing of the GJB1 gene and its promoter did not reveal any mutation. Later, a DSMAX locus was found to be flanked by the DXS8046 and DXS8114 markers (in the $14.2 \mathrm{Mb}$ region) [76].

\subsubsection{Alzheimer's Disease and Copper}

Alzheimer's disease (AD) is a progressive neurodegenerative disease characterized by development of senile plaques in the brain [77]. High levels of polyvalent cations (copper, iron, and zinc) are observed in the senile plaques in the brains of AD patients [78-80]. Mouse models were used to reveal that copper accumulates in the senile plaques of $\mathrm{AD}$ patients with neurodegeneration, however, in a PSAPP (presenilin/amyloid precursor protein) mouse model with slight neurodegeneration, no copper accumulation was observed [81]. Thus, these data highlight that copper and zinc ions are not the only culprits associated with AD pathogenesis [82]. A study revealed that abnormal copper homeostasis with an increase in the copper pool and a decrease in copper-bound proteins are the main factors causing AD [83].

Furthermore, an increased serum copper concentration in patients with AD might be associated with an increase in the concentrations of "free" copper in the blood [83,84]. Mutations in genes encoding for proteins required for copper ion uptake lead to early onset familial AD [85]. This highlights that a copper deficiency in the brain cells seems to be an important factor in AD [77].

\subsubsection{Parkinson's Disease and Copper}

There are several important pieces of evidence in the literature concerning the role of free copper in neurodegenerative diseases $[86,87]$. Occupational studies have noted that long-term exposure (20 years) to copper and manganese increases the risk of Parkinson's disease [88]. In an in vitro study, Spencer et al. (89) demonstrated that copper ions facilitate the oxidation of dopamine and other related catechols, such as $6 \mathrm{OH}-\mathrm{DOPA}$ and L-dopamine. The complexes resulting from dopamine oxidation products and copper were observed to cause intense damage to DNA [89]. Copper is required in a myriad of reactions in cell metabolism, mainly in the brain because the brain is prone to oxidative stress and has a high respiratory rate [90]. In this regard, an important physiological function of copper-dependent proteins is their redox capacity. The role of copper transporters in Parkinson's disease is an issue that 
also deserves further research [91]. Knowledge about copper compartmentalization in the brain will help to establish promissory therapeutic strategies aimed at enhancing the positive role of this metal in Parkinson's disease [92].

\section{Manganese Homeostasis}

Manganese (Mn) is a heavy metal required for several important physiological processes in humans, such as energy metabolism, antioxidant defense, and proper immune function. However, overexposure to or an excess amount of Mn can result in a condition that may be similar to Parkinson's disease (PD). In humans, the total required amount of manganese is $12-20 \mathrm{mg}$. The daily turnover is estimated to be $20 \mu \mathrm{g}$, with approximately $2-22 \mathrm{mg} /$ day as the intake, and approximately $2 \%-10 \%$ absorbed through the small intestine [16]. There is a competition between the daily iron and manganese intake in the body, as these elements compete for the same divalent metal transporter, DMT1 [16,93]. Enzymes that require Mn for proper function are presented in Table 6.

In several studies, Caenorhabditis elegans has been shown to mimic the effects of excess manganese in mammals, showing such features as neurodegeneration and an increased level of Akt and oxidative stress [94]. Genetic studies on C. elegans have uncovered several genes associated with manganese neurotoxicity. Furthermore, a significant number of studies have been conducted to decipher the role of astrocytes in manganese-induced neurotoxicity $[95,96]$. The use of a simple organism such as C. elegans that has homologous human genes has recently attracted attention for defining and discovering the exact pathway involved in manganese uptake/transport and explaining the underlying pathophysiology $[97,98]$.

Table 6. Enzymes that require manganese for proper function [4].

\begin{tabular}{|c|c|c|}
\hline S. No. & Enzyme & Function \\
\hline 1 & Prolidase & Collagen recycling (Enzyme capable of degrading dipeptides) \\
\hline 2 & Arginase & Krebs-Henseleit urea cycle (Final enzyme of the urea cycle) \\
\hline 3 & Superoxide dismutase & $\begin{array}{l}\text { Antioxidant (An enzyme that alternately catalyzes the dismutation } \\
\text { of the superoxide radical into either ordinary molecular oxygen or } \\
\text { hydrogen peroxide) }\end{array}$ \\
\hline 4 & Glycosyl tranferases & $\begin{array}{c}\text { Glycosaminoglycan synthesis (Enzymes that establish natural } \\
\text { glycosidic linkages) }\end{array}$ \\
\hline 5 & Glutamine synthetase & $\begin{array}{l}\text { Glutamine synthesis (Plays an essential role in the metabolism of } \\
\text { nitrogen by catalyzing the condensation of glutamate and } \\
\text { ammonia to form glutamine) }\end{array}$ \\
\hline 6 & Isocitrate dehydrogenase & $\begin{array}{c}\text { Krebs cycle (Catalyzes the oxidative decarboxylation of isocitrate, } \\
\text { producing alpha-ketoglutarate and } \mathrm{CO}_{2} \text { ) }\end{array}$ \\
\hline 7 & Pyruvate carboxylase & $\begin{array}{l}\text { Gluconeogenesis (It catalyzes the physiologically irreversible } \\
\text { carboxylation of pyruvate to form oxaloacetate) }\end{array}$ \\
\hline 8 & $\begin{array}{l}\text { Phosphoenolpyruvate } \\
\text { carboxykinase }\end{array}$ & $\begin{array}{l}\text { Gluconeogenesis (It converts oxaloacetate into } \\
\text { phosphoenolpyruvate and carbon dioxide) }\end{array}$ \\
\hline
\end{tabular}

\subsection{Disorders Associated with Manganese Homeostasis}

\subsubsection{Hypermanganesemia with Dystonia Type 1}

Hypermanganesemia with dystonia type 1 (OMIM 613280) is a disorder associated with improper manganese homeostasis caused by homozygous mutations in the SLC30A10 gene (OMIM 611146) located on chromosome 1q41 [99,100]. SLC30A10 (Solute carrier family 30 member 10) encodes for a manganese exporter that is expressed in the liver, small intestine, and brain [101,102]. To date, only 22 mutations in the SLC30A10 gene causing hypermanganesemia with dystonia type 1 have been reported, which mostly include small deletions (HGMD, 2018; http://www.hgmd.cf.ac.uk). 


\subsubsection{Hypermanganesemia with Dystonia Type 2}

Pathogenic mutations in the SLC39A14 gene located on chromosome 8p21.3, which encodes for ZIP14, have been associated with two different disorders [103]. Heterozygous mutations in the dominant fashion are responsible for hyperostosis cranalis interna (OMIM 144755), while biallelic mutations have been reported to cause hypermanganesemia with dystonia 2 (OMIM 617013).

The associated phenotypes includes microcephaly, bulbar dysfunction, scoliosis, axial hypotonia, intellectual disability, variable learning disability, poor or absent speech, dystonia, spasticity, abnormal gait, scissoring, and hyper-reflexia. A decrease in the uptake of manganese has been observed in several patients; thus, the liver is safe, while an elevation of manganese concentration in the blood has been observed that leads to manganese deposition in the brain [103].

The slc39a14 zebrafish model showed a buildup of manganese in the brain, while no other metals were accumulated that were associated with reduced locomotion activity. The main issue was the proper uptake of manganese into the liver, which usually allows the blood manganese level to be normalized via biliary excretion [103].

\subsubsection{Congenital Disorder of Glycosylation Type IIn}

Homozygous mutations in the SLC39A8 gene (OMIM 608732) located on chromosome 4q24 have been associated with congenital disorder of glycosylation type IIn (OMIM 616721). Clinical features associated with the disorder include short stature, eye deformity (strabismus, astigmatism, nystagmus), osteopenia, hypotonia, an inability to walk, and laboratory results suggested decreased plasma zinc and manganese levels and increased urinary zinc and manganese levels [104,105].

\section{Selenium Homeostasis}

The total selenium intake in the human body varies across different countries. In the United States, the adult intake level is 13.0-20.3 mg [106]. People living in other countries have a low intake of selenium. It is mostly found in an organic form in plant sources (selenomethionine) and animal sources (selenocysteine). In dietary supplements, it is found in inorganic forms (selenite and selenite) [107].

Selenium is mostly required for the proper activity and biosynthesis of selenoproteins. By definition, a selenoprotein is a protein with a selenocysteine ( $\mathrm{Sec}, \mathrm{U}, \mathrm{Se}-\mathrm{Cys})$ amino acid residue. Almost 25 genes in the human genome that encode for different types of selenoproteins have been identified [106,108]. The primary functions of different mammalian selenoproteins are presented in Table 7 . The intestine absorbs approximately $80 \%$ of ingested selenium [108-111]. Different disorders have been reported to be associated with mutations in the genes encoding for these selenoproteins. They are usually very complex syndromes [107].

\subsection{Disorders Associated with Manganese Homeostasis}

\subsubsection{Keshan Disease}

Keshan disease is a severe disorder that exhibits an endemic cardiomyopathy and was reported for the first time in selenium-deficient areas of China [112]. Multifocal myocarditis was observed primarily in children aged 2-10 years and, to a lesser extent, in women of childbearing age $[113,114]$. Its main manifestations are cardiac enlargement, insufficiencies in cardiac function, electrocardiographic abnormalities, arrhythmias, and radiographic abnormalities [112]. 
Table 7. Mammalian selenoproteins and their function $[107,110,111]$.

\begin{tabular}{|c|c|}
\hline Mammalian Selenoproteins & Functions \\
\hline 15 kDa selenoprotein (Sep15) & $\begin{array}{l}\text { Regulated by ER stress, interacts with the UDP-glucose glycoprotein } \\
\text { glucosyltransferase and is potentially involved in glycoprotein folding }\end{array}$ \\
\hline Thyroid hormone deiodinase 1 & $\begin{array}{c}\text { Removes iodine from the outer ring of T4 to produce plasma } \mathrm{T} 3 \text { and catalyzes } \\
\text { deiodination and thus inactivation of } \mathrm{T} 3\end{array}$ \\
\hline Thyroid hormone deiodinase 2 & Converts T4 to T3 locally in tissues \\
\hline Thyroid hormone deiodinase 3 & $\begin{array}{c}\text { Catalyzes deiodination of } \mathrm{T} 4 \text { to } \mathrm{T} 3 \text { in peripheral } \\
\text { tissues }\end{array}$ \\
\hline Glutathione peroxidase (GPx) 1-4, 6 & $\begin{array}{l}\text { GSH-dependent detoxification of } \mathrm{H} 2 \mathrm{O} 2 \\
\text { (enriched in liver, kidney, erythrocytes) }\end{array}$ \\
\hline Selenoprotein $\mathrm{H}$ & $\begin{array}{c}\text { Nuclear redox control, protects cells from } \mathrm{H} 2 \mathrm{O} 2 \text {, increases mitochondrial } \\
\text { biogenesis and } \mathrm{CytC} \text { production }\end{array}$ \\
\hline Selenoprotein I & Unknown function \\
\hline Selenoprotein R (SEPX, MSRB1) & Methionine sulfoxide reductase \\
\hline Selenoproteins $\mathrm{K}$ & Modulates $\mathrm{Ca} 2+$ influx that affects immune cells \\
\hline Selenoproteins M & Protects neurons from oxidative stress \\
\hline Selenoproteins N, & $\begin{array}{c}\text { Expressed in skeletal muscle, heart, lung, and } \\
\text { placenta }\end{array}$ \\
\hline Selenoproteins, $\mathrm{O}$ & Unknown function \\
\hline Selenoproteins, $\mathrm{T}$ & Cellular calcium handling, redox regulation, plays a role in cell adhesion \\
\hline Selenoprotein, P (SelP) & Se transport to peripheral tissues and an antioxidant function \\
\hline Selenoprotein, $\mathrm{R}$ & Reduces methionine-R-sulfoxide residues in proteins to methionine \\
\hline Selenoproteins, $\mathrm{S}$ & $\begin{array}{c}\text { Upregulated upon treatment with pro-inflammatory cytokines and glucose } \\
\text { deprivation }\end{array}$ \\
\hline Selenophosphate synthetase 2 (SPS2) & $\begin{array}{l}\text { Protein folding and degradation } \\
\text { Selenocysteine biosynthesis }\end{array}$ \\
\hline Selenoprotein P (SePP) & Se transport \\
\hline Deiodinase (DIO) 1-3 & Thyroid hormone metabolism \\
\hline Thioredoxin reductase 1 & Reduces the oxidized form of cytosolic thioredoxin \\
\hline Thioredoxi & $\begin{array}{l}\text { Catalyzes a variety of reactions, specific for } \\
\text { thioredoxin and glutaredoxin systems, and } \\
\text { expressed in spermatids }\end{array}$ \\
\hline Thioredoxin reductase 3 & $\begin{array}{l}\text { Reduces the oxidized form of mitochondrial } \\
\text { thioredoxin and glutaredoxin } 2\end{array}$ \\
\hline Selenoprotein, $\mathrm{V}$ & Unknown function and expressed in spermatids \\
\hline Selenoprotein $\mathrm{W}$ & Unknown function and expressed in skeletal muscle and other tissues \\
\hline
\end{tabular}

6.1.2. Rigid Spine Muscular Dystrophy 1 (RSMD1) and Congenital Myopathy with Fiber-Type Disproportion

Rigid spine muscular dystrophy-1 (OMIM 602771), desmin-related myopathy with Mallory bodies, congenital myopathy with fiber-type disproportion (OMIM 255310), and severe classic multiminicore myopathy have the same severe disease spectrum and are caused by a pathogenic biallelic or compound heterozygous mutation in the SEPN1 gene (OMIM 606210) located on chromosome 1p36. The SEPN1 gene is abbreviated as SELENON (Selenoprotein N) and encodes for a particular glycoprotein that is mostly localized in the endoplasmic reticulum, which plays a key role in the regulation of calcium homeostasis and protection against oxidative stress [115-117].

RSMD1 is inherited as an autosomal recessive entity. Clinical features associated with RSMD1 include short stature, low body weight, poor ability to gain weight, poor head control, failure to thrive, restrictive respiratory syndrome, reduced vital capacity, spinal rigidity, hypotonia, and other associated severe conditions [115-118].

Congenital myopathy with fiber-type disproportion (CFTD) is inherited in both an autosomal dominant and a recessive fashion. Clinical features associated with CFTD include failure to thrive, a long face, facial muscle weakness, ophthalmoplegia (in $20 \%$ of patients), ptosis, respiratory distress, decreased forced vital capacity, neonatal hypotonia, proximal muscle weakness, and some other associated conditions $[115,118]$. 


\subsubsection{Abnormal Thyroid Hormone Metabolism or SECISBP2 Syndrome}

Homozygous or compound heterozygous mutations in the SECISBP2 gene (OMIM 607693) have been associated with abnormal thyroid hormone metabolism (OMIM 609698). This syndrome is associated with such features as short stature, soft tissue weakness, proximal muscle weakness, and infiltration of fat into muscles. Laboratory tests suggest an increase in serum thyrotropin, total thyroxine $(\mathrm{T}(4))$, free thyroxine $(\mathrm{T}(4))$, and reverse triiodothyronine $(\mathrm{rT}(3))$, while triiodothyronine (T(3)) and serum selenium levels are decreased in the body [119,120]. To date, only 15 mutations causing abnormal thyroid metabolism, growth retardation, and selenoprotein-related pathogenesis have been associated with the SECISBP2 gene (HGMD, 2018; http://www.hgmd.cf.ac.uk).

\subsubsection{Pontocerebellar Hypoplasia Type 2D}

Pontocerebellar hypoplasia (PCH2D; OMIM 613811) is a rare heterogeneous neurodegenerative disorder inherited as an autosomal recessive entity. Homozygous mutations in the SEPSECS gene (OMIM 613009) have been reported to cause this severe condition, which is characterized by such features as microcephaly, contractures, an intellectual disability, clonus, seizures, sleep disturbances, cerebellar atrophy, and thin corpus callosum [121-123]. To date, only 16 mutations causing pontocerebellar hypoplasia have been associated with the SEPSECS gene (HGMD, 2018; http://www.hgmd.cf.ac.uk).

\subsubsection{Glutathione Peroxidase Deficiency}

Glutathione peroxidase deficiency (GPXD; OMIM 614164), in association with hemolytic anemia, has been reported several times in the literature. It is an autosomal recessive disorder with such hallmark clinical features as neonatal hyperbilirubinemia, interaction with selenium deficiency, hemolytic issues, compensated hemolytic anemia, and laboratory tests that reveal glutathione peroxidase deficiency and heinz bodies [124-126]. Mutations in the GPX1 gene (OMIM 138320), which is located on chromosome 3p21.31, have been associated with GPXD [127].

\subsubsection{Sedaghatian-Type Spondylometaphyseal Dysplasia (SMDS)}

SMDS (OMIM 250220) is a lethal disorder clinically characterized by platyspondyly, severe metaphyseal chondrodysplasia, delayed epiphyseal ossification, limb shortening, pulmonary hemorrhage, and irregular iliac crests. Affected individuals show severe hypotonia and cardiovascular and respiratory problems $[128,129]$. Due to respiratory failure, most patients die within a few days after birth [130]. It is an autosomal recessive disorder and compound heterozygous mutations in the GPX4 gene (OMIM 138322), which is located on chromosome 19p13.3, have been associated with SMDS [131]. GPX4 (glutathione peroxidase 4) belongs to the glutathione peroxidase family. Its isozyme is also a selenoprotein that contains the rare amino acid selenocysteine (Sec) at its active site, which is involved in catalyzing the reduction of hydrogen peroxide, lipid hydroperoxides, and organic hydroperoxides and, thus, protecting cells against oxidative damage [132].

\section{Treatment for Metal-Associated Disorders}

Disorders associated with transition metals can be effectively treated and the metal deficiency may be fulfilled by oral supplements. Treatment for metal toxicity can also be accomplished by using another metal that competes for the transport or uptake of the desired one; for example, for intestinal uptake or transport, iron competes with magnesium (DMT1). Thus, transferrin/a transferrin receptor can be utilized in those disorders where manganese accumulates [133]. Chelation therapy is also used as an alternative metal toxicity treatment. For instance, the chelation of copper is performed with such agents as trientine and penicillamine. As a treatment for disorders associated with manganese toxicity, intravenous infusion of disodium calcium edetate can be performed effectively $[99,103,133]$.

Two main factors should be kept in mind while using a chelator. The first is the stability constant, as disodium calcium edetate will only chelate metals that have the capacity to bind a higher-stability 
constant, such as calcium (Mn, $\mathrm{Fe}, \mathrm{Co}, \mathrm{Zn}, \mathrm{Cd}, \mathrm{Pb}, \mathrm{Ni}$ ). Secondly, disodium calcium edetate will bind much more efficiently to unbound metal ions as compared to bound ones [103].

Chelators and ionophores target transition metal homeostasis at the molecular level by binding and releasing metals with the aim of eliminating excess metals, depositing exogenous metals, or redistributing endogenous metals. Ionophores and chelators may work opposite one another, as ionophores are responsible for the delivery of metals and chelators remove metals. Ultimately, they both act as metal-binding molecules [6]. Chelators and ionophores have application as metal-binding molecules in different diseases, including cancer $[134,135]$ and neurodegenerative diseases $[6,136]$. Researchers are developing chelators and ionophores for drugs that target metal homeostasis, and these chelators and ionophores are making their way into clinical trials for the treatment of cancer and neurodegenerative diseases $[137,138]$.

\section{Conclusions}

Metabolic disorders related to metals are regarded as quintessential single-gene disorders. However, in recent years, advances in next-generation sequencing and other advanced technologies have revealed that the classical "one gene-one enzyme" paradigm is not always the culprit. It has been reported that defects in multiple genes may lead to the same phenotypic presentation. Furthermore, mutations in different domains of the same protein might produce a difference in the phenotypes. Thus, it very difficult to pin-point a specific mutation and proceed with therapeutic strategies as different mutations respond differently during therapy. This process is not homogeneous across diseases and specific mutations.

In addition, next-generation sequencing has also shown that affected individuals with hybrid phenotypes might have mutations in more than two different genes that are responsible for causing more than two phenotypes in the same individual, which leads to a complex phenotype. Such complex genetic disorders are very difficult to diagnose and become increasingly difficult to manage with a therapeutic plan. Newly discovered disease-causing genes and disorders associated with metal metabolism have provided us with insight into the basics of the micronutrients that are required for the proper maintenance of the human body. Advances in the fields of molecular diagnostics and precision medicine have allowed us to understand more about the metabolism, regulation, and functions of these micronutrients, which will ultimately lead to new therapeutic strategies. However, we still have a lot to learn.

Funding: No funding source was involved.

Conflicts of Interest: The authors have no conflicts of interest.

\section{References}

1. Ayton, S.; Lei, P.; Bush, A.I. Metallostasis in Alzheimer's disease. Free Radic. Biol. Med. 2013, 62, 76-89. [CrossRef] [PubMed]

2. Rines, A.K.; Ardehali, H. Transition metals and mitochondrial metabolism in the heart. J. Mol. Cell Cardiol. 2013, 55, 50-57. [CrossRef] [PubMed]

3. Dusek, P.; Litwin, T.; Czlonkowska, A. Wilson disease and other neurodegenerations with metal accumulations. Neurol. Clin. 2015, 33, 175-204. [CrossRef] [PubMed]

4. Ferreira, C.R.; Gahl, W.A. Disorders of metal metabolism. Transl. Sci. Rare Dis. 2017, 2, 101-139. [CrossRef] [PubMed]

5. Barnham, K.J.; Bush, A.I. Biological metals and metal-targeting compounds in major neurodegenerative diseases. Chem. Soc. Rev. 2014, 43, 6727-6749. [CrossRef] [PubMed]

6. Weekley, C.M.; He, C. Developing drugs targeting transition metal homeostasis. Curr. Opin. Chem. Biol. 2017, 37, 26-32. [CrossRef]

7. Tang, J.; Yin, H.Y.; Zhang, J.L. Chapter One-Luminescent Zinc Complexes as Bioprobes for Imaging Molecular Events in Live Cells. In Inorganic and Organometallic Transition Metal Complexes with Biological Molecules and Living Cells; Academic Press: Cambridge, MA, USA, 2017; pp. 1-53. [CrossRef] 
8. Zecca, L.; Youdim, M.B.; Riederer, P.; Connor, J.R.; Crichton, R.R. Iron, brain ageing and neurodegenerative disorders. Nat. Rev. Neurosci. 2004, 5, 863-873. [CrossRef]

9. Ellwanger, J.H.; Franke, S.I.; Bordin, D.L.; Prá, D.; Henriques, J.A. Biological functions of selenium and its potential influence on Parkinson's disease. An. Acad Bras. Cienc. 2016, 88, 1655-1674. [CrossRef]

10. Giampietro, R.; Spinelli, F.; Contino, M.; Colabufo, N.A. The Pivotal Role of Copper in Neurodegeneration: A New Strategy for the Therapy of Neurodegenerative Disorders. Mol. Pharm. 2018, 15, 808-820. [CrossRef]

11. Huebl, J.; Poshtiban, A.; Brücke, C.; Siegert, S.; Bock, A. Subthalamic and pallidal oscillatory activity in patients with Neurodegeneration with Brain Iron Accumulation type I (NBIA-I). Clin. Neurophysiol. 2019, 130, 469-473. [CrossRef]

12. Martins, A.C.; Morcillo, P.; Ijomone, O.M.; Venkataramani, V.; Harrison, F.E. New Insights on the Role of Manganese in Alzheimer's Disease and Parkinson's Disease. Int. J. Environ. Res. Public Health 2019, 16, 3546. [CrossRef] [PubMed]

13. Maret, W. Zinc biochemistry: From a single zinc enzyme to a key element of life. Adv. Nutr. 2013, 4, 82-91. [CrossRef] [PubMed]

14. Maverakis, E.; Fung, M.A.; Lynch, P.J.; Draznin, M.; Michael, D.J.; Ruben, B. Acrodermatitis enteropathica and an overview of zinc metabolism. J. Am. Acad Dermatol. 2007, 56, 116-124. [CrossRef]

15. Kambe, T.; Tsuji, T.; Hashimoto, A.; Itsumura, N. The Physiological, Biochemical, and Molecular Roles of Zinc Transporters in Zinc Homeostasis and Metabolism. Physiol. Rev. 2015, 95, 749-784. [CrossRef] [PubMed]

16. Chen, P.; Bornhorst, J.; Aschner, M. Manganese metabolism in humans. Front. Biosci. (Landmark Ed.) 2018, 23, 1655-1679. [CrossRef] [PubMed]

17. Clayton, P.T. Inherited disorders of transition metal metabolism: An update. J. Inherit. Metab. Dis. 2017, 40, 519-529. [CrossRef]

18. Küry, S.; Dréno, B.; Bézieau, S.; Giraudet, S.; Kharfi, M.; Kamoun, R.; Moisan, J.P. Identification of SLC39A4, a gene involved in acrodermatitis enteropathica. Nat. Genet. 2002, 31, 239-240. [CrossRef]

19. Andrews, G.K. Regulation and function of Zip4, the acrodermatitis enteropathica gene. Biochem. Soc. Trans. 2008, 36, 1242-1246. [CrossRef]

20. Schmitt, S.; Küry, S.; Giraud, M.; Dréno, B.; Kharfi, M.; Bézieau, S. An update on mutations of the SLC39A4 gene in acrodermatitis enteropathica. Hum. Mutat. 2009, 30, 926-933. [CrossRef]

21. Chowanadisai, W.; Lönnerdal, B.; Kelleher, S.L. Identification of a mutation in SLC30A2 (ZnT-2) in women with low milk zinc concentration that results in transient neonatal zinc deficiency. J. Biol. Chem. 2006, 281, 39699-39707. [CrossRef]

22. Lasry, I.; Seo, Y.A.; Ityel, H.; Shalva, N.; Pode-Shakked, B.; Glaser, F. A dominant negative heterozygous G87R mutation in the zinc transporter, ZnT-2 (SLC30A2), results in transient neonatal zinc deficiency. J. Biol. Chem. 2012, 287, 29348-29361. [CrossRef] [PubMed]

23. Itsumura, N.; Inamo, Y.; Okazaki, F.; Teranishi, F.; Narita, H.; Kambe, T.; Kodama, H. Compound heterozygous mutations in SLC30A2/ZnT2 results in low milk zinc concentrations: A novel mechanism for zinc deficiency in a breast-fed infant. PLoS ONE 2013, 8, e64045. [CrossRef] [PubMed]

24. Giunta, C.; Elçioglu, N.H.; Albrecht, B.; Eich, G.; Chambaz, C.; Janecke, A.R. Spondylocheiro dysplastic form of the Ehlers-Danlos syndrome-an autosomal-recessive entity caused by mutations in the zinc transporter gene SLC39A13. Am. J. Hum. Genet. 2008, 82, 1290-1305. [CrossRef] [PubMed]

25. Fukada, T.; Civic, N.; Furuichi, T.; Shimoda, S.; Mishima, K.; Higashiyama, H. The zinc transporter SLC39A13/ZIP13 is required for connective tissue development; its involvement in BMP/TGF-beta signaling pathways. PLoS ONE 2008, 3, e3642. [CrossRef]

26. Perez, Y.; Shorer, Z.; Liani-Leibson, K.; Chabosseau, P.; Kadir, R.; Volodarsky, M. SLC30A9 mutation affecting intracellular zinc homeostasis causes a novel cerebro-renal syndrome. Brain 2017, 140, 928-939. [CrossRef]

27. Alexander, J.; Kowdley, K.V. HFE-associated hereditary hemochromatosis. Genet Med. 2009, 11, $307-313$. [CrossRef]

28. Kumar, V.; Abbas, A.K.; Fausto, N. Robbins and Cotran: Pathologic Basis of Disease. J. Neuropathol. Exp. Neurol. 2010, 69, 214.

29. Troost, D.; van Rossum, A.; Straks, W.; Willemse, J. Menkes' kinky hair disease. II. A clinicopathological report of three cases. Brain Dev. 1982, 4, 115-126. [CrossRef]

30. Barupala, D.P.; Dzul, S.P.; Riggs-Gelasco, P.J.; Stemmler, T.L. Synthesis, delivery and regulation of eukaryotic heme and Fe-S cluster cofactors. Arch. Biochem. Biophys. 2006, 592, 60-75. [CrossRef] 
31. Ahting, U.; Mayr, J.A.; Vanlander, A.V.; Hardy, S.A.; Santra, S.; Makowski, C. Clinical, biochemical, and genetic spectrum of seven patients with NFU1 deficiency. Front Genet. 2015, 6, 123. [CrossRef]

32. Rahman, S.; Mayr, J.A. Disorders of oxidative phosphorylation. In Inbornmetabolic Diseases; Saudubray, J.M., Ed.; Springer: Berlin, Germany, 2016.

33. Del-Castillo-Rueda, A.; Moreno-Carralero, M.I.; Cuadrado-Grande, N.; Alvarez-Sala-Walther, L.A.; Enríquez-de-Salamanca, R. Mutations in the HFE, TFR2, and SLC40A1 genes in patients with hemochromatosis. Gene 2012, 508, 15-20. [CrossRef] [PubMed]

34. Moreno-Carralero, M.I.; Muñoz-Muñoz, J.A.; Cuadrado-Grande, N.; López-Rodríguez, R.; José Hernández-Alfaro, M. A novel mutation in the SLC40A1 gene associated with reduced iron export in vitro. Am. J. Hematol. 2014, 89, 689-694. [CrossRef] [PubMed]

35. Gehrke, S.G.; Kulaksiz, H.; Herrmann, T.; Riedel, H.D.; Bents, K.; Veltkamp, C.; Stremmel, W. Expression of hepcidin in hereditary hemochromatosis: Evidence for a regulation in response to the serum transferrin saturation and to non-transferrinbound iron. Blood. 2003, 102, 371-376. [CrossRef]

36. Nichols, G.M.; Bacon, B.R. Hereditary hemochromatosis: Pathogenesis and clinical features of a common disease. Am. J. Gastroenterol. 1989, 84, 851-862. [PubMed]

37. Beutler, E.; Bothwell, T.H.; Charlton, R.W.; Motulsky, A.G. Hereditary Hemochromatosis. Available online: http://mhmedical.com/content.aspx?aid=1102891675 (accessed on 8 December 2009).

38. Levi, S.; Tiranti, V. Neurodegeneration with Brain Iron Accumulation Disorders: Valuable Models Aimed at Understanding the Pathogenesis of Iron Deposition. Pharmaceuticals (Basel) 2019, 12, 27. [CrossRef] [PubMed]

39. Kruer, M.C. The neuropathology of neurodegeneration with brain iron accumulation. Int. Rev. Neurobiol. 2013, 110, 165-194. [CrossRef]

40. Kono, S.; Miyajima, H. Molecular and pathological basis of aceruloplasminemia. Biol. Res. 2006, 39 , 15-23. [CrossRef]

41. Meral Gunes, A.; Sezgin Evim, M.; Baytan, B.; Iwata, A.; Hida, A.; Avci, R. Aceruloplasminemia in a Turkish adolescent with a novel mutation of ceruloplasmin gene: The first diagnosed case from Turkey. J. Pediatr. Hematol. Oncol. 2014, 36, e423-e425. [CrossRef]

42. Ferrari, F.; Foglieni, B.; Arosio, P.; Camaschella, C.; Daraio, F.; Levi, S.; García Erce, J.A. Microelectronic DNA chip for hereditary hyperferritinemia cataract syndrome, a model for large-scale analysis of disorders of iron metabolism. Hum. Mutat. 2006, 27, 201-208. [CrossRef]

43. Gonzalez-Huerta, L.; Ramirez-Sanchez, V.; Rivera-Vega, M.; Messina-Baas, O.; Cuevas-Covarrubias, S. A family with hereditary hyperferritinaemia cataract syndrome: Evidence of incomplete penetrance and clinical heterogeneity. Br. J. Haematol. 2008, 143, 596-598. [CrossRef]

44. Danks, D.M. Disorders of copper transport. In Metabolic and Molecular Bases of Inherited Diseases, 7th ed.; Scriver, C.R., Beaudet, A.L., Sly, W.S., Valle, D.L., Eds.; McGraw Hill: New York, NY, USA, 1995.

45. Burkhead, J.L.; Reynolds, K.A.; Abdel-Ghany, S.E.; Cohu, C.M.; Pilon, M. Copper homeostasis. Neww. Phytol. 2009, 182, 799-816. [CrossRef] [PubMed]

46. Palmiter, R.D. The elusive function of metallothioneins. Proc. Natl. Acad. Sci. USA 1998, 95, 8428-8430. [CrossRef] [PubMed]

47. Healy, J.; Tipton, K. Ceruloplasmin and what it might do. J. Neural Transm (Vienna) 2007, 114, 777-781. [CrossRef] [PubMed]

48. Vashchenko, G.; MacGillivray, R.T. Multi-copper oxidases and human iron metabolism. Nutrients 2013, 5, 2289-2313. [CrossRef]

49. Weiss, K.H. Wilson Disease. Available online: http://www.ncbi.nlm.nih.gov/books/NBK1512/ (accessed on 29 July 2016).

50. Scheinberg, I.H.; Sternlieb, I. Wilson's disease. Lancet 1984, 369, 397-408.

51. Bull, P.C.; Thomas, G.R.; Rommens, J.M.; Forbes, J.R.; Cox, D.W. The Wilson disease gene is a putative copper transporting P-type ATPase similar to the Menkes gene. Nat. Genet. 1993, 5, 327-337. [CrossRef]

52. Petrukhin, K.; Fischer, S.G.; Pirastu, M.; Tanzi, R.E.; Chernov, I.; Devoto, M.; Brzustowicz, L.M. Mapping cloning and genetic characterization of the region containing the Wilson disease gene. Nat. Genet. 1993, 5 , 338-343. [CrossRef]

53. Chelly, J.; Monaco, A.P. Cloning the Wilson disease gene. Nat. Genet. 1993, 5, 317-318. [CrossRef]

54. Coffey, A.J.; Durkie, M.; Hague, S.; McLay, K.; Emmerson, J.; Lo, C. A genetic study of Wilson's disease in the United Kingdom. Brain 2013, 136, 1476-1487. [CrossRef] 
55. Li, K.; Zhang, W.M.; Lin, S.; Wen, L.; Wang, Z.F.; Xie, D. Mutational analysis of ATP7B in north Chinese patients with Wilson disease. J. Hum. Genet. 2013, 58, 67-72. [CrossRef]

56. Stenson, P.D.; Mort, M.; Ball, E.V.; Shaw, K.; Phillips, A.; Cooper, D.N. The human gene mutation database: Building a comprehensive mutation repository for clinical and molecular genetics, diagnostic testing and personalized genomic medicine. Hum. Genet. 2014, 133, 1-9. [CrossRef] [PubMed]

57. van Hasselt, P.M.; Clayton, P.; Houwen, R.H.J. Disorders in the transport of copper, iron, magnesium, manganese, selenium and zinc. In Diagnosis and Treatment Inborn Metabolic Diseases, 6th ed.; Saudubray, J.M., Baumgartner, M.R., Walter, J., Eds.; Springer: Berlin, Germany, 2016.

58. Schlaug, G.; Hefter, H.; Engelbrecht, V.; Kuwert, T.; Arnold, S.; Stöcklin, G.; Seitz, R.J. Neurological impairment and recovery in Wislon's disease: Evidence from PET and MRI. J. Neurol. Sci. 1996, 136, 129-139. [CrossRef]

59. Członkowska, A.; Litwin, T.; Karliński, M.; Dziezyc, K.; Chabik, G.; Czerska, M. D-penicillamine versus zinc sulfate as first-line therapy for Wilson's disease. Eur. J. Neurol. 2014, 21, 599-606. [CrossRef] [PubMed]

60. Litwin, T.; Dzieżyc, K.; Karliński, M.; Chabik, G.; Czepiel, W.; Członkowska, A. Early neurological worsening in patients with Wilson's disease. J. Neurol. Sci. 2015, 355, 162-167. [CrossRef]

61. Dhawan, A.; Taylor, R.M.; Cheeseman, P.; De Silva, P.; Katsiyiannakis, L.; Mieli-Vergani, G. Wilson's disease in children: 37-year experience and revised King's score for liver transplantation. Liver Transpl. 2005, 11, 441-448. [CrossRef]

62. Lichtmannegger, J.; Leitzinger, C.; Wimmer, R.; Schmitt, S.; Schulz, S.; Kabiri, Y. Methanobactin reverses acute liver failure in a rat model of Wilson disease. J. Clin. Investig. 2016, 126, 2721-2735. [CrossRef]

63. Martinelli, D.; Travaglini, L.; Drouin, C.A.; Ceballos-Picot, I.; Rizza, T.; Bertini, E. MEDNIK syndrome: A novel defect of copper metabolism treatable by zinc acetate therapy. Brain 2013, 136, 872-881. [CrossRef]

64. Incecik, F.; Bisgin, A.; Y1lmaz, M. MEDNIK syndrome with a frame shift causing mutation in AP1S1 gene and literature review of the clinical features. Metab. Brain Dis. 2018, 33, 2065-2068. [CrossRef]

65. Menkes, J.H.; Alter, M.; Steigleder, G.K.; Weakley, D.R.; Sung, J.H. A sex-linked recessive disorder with retardation of growth, peculiar hair, and focal cerebral and cerebellar degeneration. Pediatrics 1962, 29, 764-779.

66. Kaler, S.G. Menkes disease. Adv. Pediatr. 1994, 41, 263-304.

67. Kaler, S.G. ATP7A-Related Copper Transport Disorders. Available online: http://www.ncbi.nlm.nih.gov/ books/NBK1413/ (accessed on 18 August 2016).

68. Kaler, S. ATP7A-Related Copper Transport Disorders. GeneReviews; 14 October 2010. Available online: http://www.ncbi.nlm.nih.gov/books/NBK1413/\#top (accessed on 8 December 2019).

69. Gualandi, F.; Sette, E.; Fortunato, F.; Bigoni, S.; De Grandis, D. Report of a novel ATP7A mutation causing distal motor neuropathy. Neuromuscul. Disord. 2019, 29, 776-785. [CrossRef] [PubMed]

70. Tsukahara, M.; Imaizumi, K.; Kawai, S.; Kajii, T. Occipital horn syndrome: Report of a patient and review of the literature. Clin. Genet. 1994, 45, 32-35. [CrossRef] [PubMed]

71. Ronce, N.; Moizard, M.P.; Robb, L.; Toutain, A.; Villard, L.; Moraine, C. A C2055T transition in exon 8 of the ATP7A gene is associated with exon skipping in an occipital horn syndrome family. Am. J. Hum. Genet. 1997, 61, 233-238. [CrossRef]

72. Yasmeen, S.; Lund, K.; De Paepe, A.; De Bie, S.; Heiberg, A. Occipital horn syndrome and classical Menkes Syndrome caused by deep intronic mutations, leading to the activation of ATP7A pseudo-exon. Eur. J. Hum. Genet. 2014, 22, 517-521. [CrossRef] [PubMed]

73. Polishchuk, R.; Lutsenko, S. Golgi in copper homeostasis: A view from the membrane trafficking field. Histochem. Cell Biol. 2013, 140, 285-295. [CrossRef] [PubMed]

74. Huppke, P.; Brendel, C.; Kalscheuer, V.; Korenke, G.C.; Marquardt, I. Mutations in SLC33A1 cause a lethal autosomal-recessive disorder with congenital cataracts, hearing loss, and low serum copper and ceruloplasmin. Am. J. Hum. Genet. 2012, 90, 61-68. [CrossRef] [PubMed]

75. Chiplunkar, S.; Bindu, P.S.; Nagappa, M.; Bineesh, C.; Govindaraj, P. Huppke-Brendel syndrome in a seven months old boy with a novel 2-bp deletion in SLC33A1. Metab. Brain Dis. 2016, 31, 1195-1198. [CrossRef]

76. Kennerson, M.; Nicholson, G.; Kowalski, B.; Krajewski, K.; El-Khechen, D. X-linked distal hereditary motor neuropathy maps to the DSMAX locus on chromosome Xq13.1-q21. Neurology 2009, 72, 246-252. [CrossRef]

77. Bagheri, S.; Squitti, R.; Haertlé, T.; Siotto, M.; Saboury, A.A. Role of Copper in the Onset of Alzheimer's Disease Compared to Other Metals. Front Aging Neurosci. 2018, 9, 446. [CrossRef] 
78. Sayre, L.M.; Perry, G.; Harris, P.L.; Liu, Y.; Schubert, K.A.; Smith, M.A. In situ oxidative catalysis by neurofibrillary tangles and senile plaques in Alzheimer's disease. J. Neurochem. 2000, 74, 270-279. [CrossRef]

79. Dong, J.; Atwood, C.S.; Anderson, V.E.; Siedlak, S.L.; Smith, M.A.; Perry, G.; Carey, P.R. Metal binding and oxidation of amyloid-b within isolated senile plaque cores: Raman microscopic evidence. Biochemistry 2003, 42, 2768-2773. [CrossRef] [PubMed]

80. Miller, L.M.; Wang, Q.; Telivala, T.P.; Smith, R.J.; Lanzirotti, A.; Miklossy, J. Synchrotron-based infrared and X-ray imaging shows focalized accumulation of $\mathrm{Cu}$ and $\mathrm{Zn}$ co-localized with beta-amyloid deposits in Alzheimer's disease. J. Struct Biol. 2006, 155, 30-37. [CrossRef] [PubMed]

81. James, S.A.; Churches, Q.I.; de Jonge, M.D.; Birchall, I.E.; Streltsov, V. Iron, Copper, and Zinc Concentration in A $\beta$ Plaques in the APP/PS1 Mouse Model of Alzheimer's Disease Correlates with Metal Levels in the Surrounding Neuropil. ACS Chem. Neurosci. 2017, 8, 629-637. [CrossRef] [PubMed]

82. Singh, I.; Sagare, A.P.; Coma, M.; Perlmutter, D.; Gelein, R.; Bell, R.D. Low levels of copper disrupt brain amyloid- $\beta$ homeostasis by altering its production and clearance. Proc. Natl. Acad. Sci. USA 2013, 110, 14771-14776. [CrossRef] [PubMed]

83. Squitti, R.; Siotto, M.; Arciello, M.; Rossi, L. Non-ceruloplasmin bound copper and ATP7B gene variants in Alzheimer's disease. Metallomics 2016, 8, 863-873. [CrossRef]

84. Talwar, P.; Grover, S.; Sinha, J.; Chandna, P.; Agarwal, R. Multifactorial Analysis of a Biomarker Pool for Alzheimer Disease Risk in a North Indian Population. Dement. Geriatr. Cogn. Disord. 2017, 44, $25-34$. [CrossRef]

85. Southon, A.; Greenough, M.A.; Ganio, G.; Bush, A.I.; Burke, R.; Camakaris, J. Presenilin promotes dietary copper uptake. PLoS ONE 2013, 8, e62811. [CrossRef]

86. Cruces-Sande, A.; Méndez-Álvarez, E.; Soto-Otero, R. Copper increases the ability of 6-hydroxydopamine to generate oxidative stress and the ability of ascorbate and glutathione to potentiate this effect: Potential implications in Parkinson's disease. J. Neurochem. 2017, 141, 738-749. [CrossRef]

87. McLeary, F.A.; Rcom-H'cheo-Gauthier, A.N.; Goulding, M.; Radford, R.A.W.; Okita, Y. Switching on Endogenous Metal Binding Proteins in Parkinson's Disease. Cells 2019, 8, 179. [CrossRef]

88. Gorell, J.M.; Johnson, C.C.; Rybicki, B.A.; Peterson, E.L.; Kortsha, G.X. Occupational exposure to manganese, copper, lead, iron, mercury and zinc and the risk of Parkinson's disease. Neurotoxicology 1999, 20, $239-247$.

89. Spencer, W.A.; Jeyabalan, J.; Kichambre, S.; Gupta, R.C. Oxidatively generated DNA damage after Cu(II) catalysis of dopamine and related catecholamine neurotransmitters and neurotoxins: Role of reactive oxygen species. Free Radic. Biol. Med. 2011, 50, 139-147. [CrossRef] [PubMed]

90. Tapiero, H.; Townsend, D.M.; Tew, K.D. Trace elements in human physiology and pathology. Copper. Biomed. Pharmacother. 2003, 57, 386-398. [CrossRef]

91. Davies, K.M.; Bohic, S.; Carmona, A.; Ortega, R.; Cottam, V. Copper pathology in vulnerable brain regions in Parkinson's disease. Neurobiol. Aging 2014, 35, 858-866. [CrossRef] [PubMed]

92. Montes, S.; Rivera-Mancia, S.; Diaz-Ruiz, A.; Tristan-Lopez, L.; Rios, C. Copper and copper proteins in Parkinson's disease. Oxid Med. Cell Longev. 2014, 2014, 147251. [CrossRef] [PubMed]

93. Tuschl, K.; Mills, P.B.; Clayton, P.T. Clayton, Manganese and the brain. Int. Rev. Neurobiol. 2013, 110, $277-312$. [CrossRef]

94. Peres, T.V.; Arantes, L.P.; Miah, M.R.; Bornhorst, J.; Schwerdtle, T. Role of Caenorhabditis elegans AKT-1/2 and SGK-1 in Manganese Toxicity. Neurotox Res. 2018, 34, 584-596. [CrossRef]

95. Bornhorst, J.; Chakraborty, S.; Meyer, S.; Lohren, H.; Brinkhaus, S.G.; Knight, A.L. The effects of pdr1, djr1.1 and pink1 loss in manganese-induced toxicity and the role of $\alpha$-synuclein in C. elegans. Metallomics 2014, 6, 476-490. [CrossRef]

96. Ke, T.; Sidoryk-Wegrzynowicz, M.; Pajarillo, E.; Rizor, A.; Soares, F.A.A. Role of Astrocytes in Manganese Neurotoxicity Revisited. Neurochem. Res. 2019. [CrossRef]

97. Au, C.; Benedetto, A.; Aschner, M. Manganese transport in eukaryotes: The role of DMT1. Neurotoxicology 2008, 569-576. [CrossRef]

98. Pinkas, A.; Aschner, M. Advanced glycation end-products and their receptors: Related pathologies, recent therapeutic strategies, and a potential model for future neurodegeneration studies. Chem. Res. Toxicol. 2016, 29, 707-714. [CrossRef] 
99. Tuschl, K.; Clayton, P.T.; Gospe, S.M.; Gulab, S.; Ibrahim, S.; Singhi, P. Syndrome of hepatic cirrhosis, dystonia, polycythemia, and hypermanganesemia caused by mutations in SLC30A10, a manganese transporter in man. Am. J. Hum. Genet. 2012, 90, 457-466. [CrossRef] [PubMed]

100. Quadri, M.; Federico, A.; Zhao, T.; Breedveld, G.J.; Battisti, C.; Delnooz, C. Mutations in SLC30A10 cause parkinsonism and dystonia with hypermanganesemia, polycythemia, and chronic liver disease. Am. J. Hum. Genet. 2012, 90, 467-477. [CrossRef]

101. Bosomworth, H.J.; Thornton, J.K.; Coneyworth, L.J.; Ford, D.; Valentine, R.A. Efflux function, tissue-specific expression and intracellular trafficking of the Zn transporter ZnT10 indicate roles in adult Zn homeostasis. Metallomics 2012, 4, 771-779. [CrossRef] [PubMed]

102. Leyva-Illades, D.; Chen, P.; Zogzas, C.E.; Hutchens, S.; Mercado, J.M.; Swaim, C.D. SLC30A10 Is a Cell Surface-Localized Manganese Efflux Transporter, and Parkinsonism-Causing Mutations Block Its Intracellular Trafficking and Efflux Activity. J. Neurosci. 2014, 34, 14079-14095. [CrossRef] [PubMed]

103. Tuschl, K.; Meyer, E.; Valdivia, L.E.; Zhao, N.; Dadswell, C.; Abdul-Sada, A. Mutations in SLC39A14 disrupt manganese homeostasis and cause childhood-onset parkinsonism-dystonia. Nat. Commun. 2016, 7, 11601. [CrossRef]

104. Fujishiro, H.; Himeno, S. New Insights into the Roles of ZIP8, a Cadmium and Manganese Transporter, and Its Relation to Human Diseases. Biol. Pharm. Bull. 2019, 42, 1076-1082. [CrossRef]

105. Anagianni, S.; Tuschl, K. Genetic Disorders of Manganese Metabolism. Curr. Neurol. Neurosci. Rep. 2019, 19, 33. [CrossRef]

106. Kryukov, G.V.; Castellano, S.; Novoselov, S.V.; Lobanov, A.V.; Zehtab, O.; Guigó, R. Characterization of mammalian selenoproteomes. Science 2003, 300, 1439-1443. [CrossRef]

107. Kasaikina, M.V.; Hatfield, D.L.; Gladyshev, V.N. Understanding selenoprotein function and regulation through the use of rodent models. Biochim. Biophys. Acta 2012, 1823, 1633-1642. [CrossRef]

108. Adani, G.; Filippini, T.; Michalke, B.; Vinceti, M. Selenium and Other Trace Elements in the Etiology of Parkinson's Disease: A Systematic Review and Meta-Analysis of Case-Control Studies. Neuroepidemiology 2019, 1-23. [CrossRef]

109. Reeves, M.A.; Hoffmann, P.R. The human selenoproteome: Recent insights into functions and regulation. Cell Mol. Life Sci. 2009, 66, 2457-2478. [CrossRef] [PubMed]

110. Schweizer, U.; Dehina, N.; Schomburg, L. Disorders of selenium metabolism and selenoprotein function. Curr. Opin. Pediatr. 2011, 23, 429-435. [CrossRef] [PubMed]

111. Rederstorff, M.; Krol, A.; Lescure, A. Understanding the importance of selenium and selenoproteins in muscle function. Cell Mol. Life Sci. 2006, 63, 52-59. [CrossRef]

112. Ge, K.; Yang, G. The epidemiology of selenium deficiency in the etiological study of endemic diseases in China. Am. J. Clin. Nutr. 1993, 57, 259S-263S. [CrossRef] [PubMed]

113. Keshan Disease Research Group. Observations on effect of sodium selenite in prevention of Keshan Disease. Chin. Med. J. (Engl.) 1979, 92, 471-476.

114. Xu, G.L.; Wang, S.C.; Gu, B.Q.; Yang, Y.X.; Song, H.B. Further investigation on the role of selenium deficiency in the aetiology and pathogenesis of Keshan disease. Biomed. Environ. Sci. 1997, 10, 316-326.

115. Erazo-Torricelli, R. Structural congenital myopathies. Rev. Neurol. 2013, 57, S53-S64.

116. Saini, A.G.; Padmanabha, H.; Kumar, S.; Sankhyan, N.; Singhi, P. SEPN1-related Rigid Spine Muscular Dystrophy. Indian J. Pediatr. 2018, 85, 1033-1034. [CrossRef]

117. Ziyaee, F.; Shorafa, E.; Dastsooz, H.; Habibzadeh, P.; Nemati, H.; Saeed, A. A novel mutation in SEPN1 causing rigid spine muscular dystrophy 1: A Case report. BMC Med. Genet. 2019, 20, 13. [CrossRef]

118. Ardissone, A.; Bragato, C.; Blasevich, F.; Maccagnano, E.; Salerno, F.; Gandioli, C. SEPN1-related myopathy in three patients: Novel mutations and diagnostic clues. Eur. J. Pediatr. 2016, 175, 1113-1118. [CrossRef]

119. Dumitrescu, A.M.; Liao, X.H.; Abdullah, M.S.; Lado-Abeal, J.; Majed, F.A.; Moeller, L.C. Mutations in SECISBP2 result in abnormal thyroid hormone metabolism. Nat. Genet. 2005, 37, 1247-1252. [CrossRef] [PubMed]

120. Schoenmakers, E.; Agostini, M.; Mitchell, C.; Schoenmakers, N.; Papp, L.; Rajanayagam, O. Mutations in the selenocysteine insertion sequence-binding protein 2 gene lead to a multisystem selenoprotein deficiency disorder in humans. J. Clin. Investig. 2010, 120, 4220-4235. [CrossRef] [PubMed]

121. Agamy, O.; Ben Zeev, B.; Lev, D.; Marcus, B.; Fine, D. Mutations disrupting selenocysteine formation cause progressive cerebello-cerebral atrophy. Am. J. Hum. Genet. 2010, 87, 538-544. [CrossRef] [PubMed] 
122. Zhu, X.; Petrovski, S.; Xie, P.; Ruzzo, E.K.; Lu, Y.F. Whole-exome sequencing in undiagnosed genetic diseases: Interpreting 119 trios. Genet. Med. 2015, 17, 774-781. [CrossRef] [PubMed]

123. van Dijk, T.; Vermeij, J.D.; van Koningsbruggen, S.; Lakeman, P.; Baas, F. Poll-The BT. A SEPSECS mutation in a 23-year-old woman with microcephaly and progressive cerebellar ataxia. J. Inherit. Metab. Dis. 2018, 41, 897-898. [CrossRef] [PubMed]

124. Perona, G.; Guidi, G.C.; Piga, A.; Cellerino, R.; Milani, G. Neonatal erythrocyte glutathione peroxidase deficiency as a consequence of selenium imbalance during pregnancy. Br. J. Haematol. 1979, 42, 567-574. [CrossRef]

125. Cohen, H.J.; Brown, M.R.; Hamilton, D.; Lyons-Patterson, J.; Avissar, N.; Liegey, P. Glutathione peroxidase and selenium deficiency in patients receiving home parenteral nutrition: Time course for development of deficiency and repletion of enzyme activity in plasma and blood cells. Am. J. Clin. Nutr. 1989, 49, 132-139. [CrossRef]

126. Cohen, H.J.; Chovaniec, M.E.; Mistretta, D.; Baker, S.S. Selenium repletion and glutathione peroxidase-differential effects on plasma and red blood cell enzyme activity. Am. J. Clin. Nutr. 1985, 41, 735-747. [CrossRef]

127. Johannsmann, R.; Hellkuhl, B.; Grzeschik, K.H. Regional mapping of human chromosome 3. Assignment of a glutathione peroxidase-1 gene to 3p13 leads to 3q12. Hum. Genet. 1981, 56, 361-363. [CrossRef]

128. Sedaghatian, M.R. Congenital lethal metaphyseal chondrodysplasia: A newly recognized complex autosomal recessive disorder. Am. J. Med. Genet. 1980, 6, 269-274. [CrossRef]

129. English, S.J.; Gayatri, N.; Arthur, R.; Crow, Y.J. Sedaghatian spondylometaphyseal dysplasia with pachygyria and absence of the corpus callosum. Am. J. Med. Genet. A 2006, 140, 1854-1858. [CrossRef] [PubMed]

130. Aygun, C.; Celik, F.C.; Nural, M.S.; Azak, E.; Kucukoduk, S. Simplified gyral pattern with cerebellar hypoplasia in Sedaghatian type spondylometaphyseal dysplasia: A clinical report and review of the literature. Am. J. Med. Genet. A 2012, 158, 1400-1405. [CrossRef] [PubMed]

131. Smith, A.C.; Mears, A.J.; Bunker, R.; Ahmed, A.; MacKenzie, M. Mutations in the enzyme glutathione peroxidase 4 cause Sedaghatian-type spondylometaphyseal dysplasia. J. Med. Genet. 2014, 51, 470-474. [CrossRef] [PubMed]

132. Kinowaki, Y.; Kurata, M.; Ishibashi, S.; Ikeda, M.; Tatsuzawa, A. Glutathione peroxidase 4 overexpression inhibits ROS-induced cell death in diffuse large B-cell lymphoma. Lab. Investig. 2018, 98, 609-619. [CrossRef] [PubMed]

133. Tuschl, K.; Mills, P.B.; Parsons, H.; Malone, M.; Fowler, D.; Bitner-Glindzicz, M.; Clayton, P.T. Hepatic cirrhosis, dystonia, polycythaemia and hypermanganesaemia-a new metabolic disorder. J. Inherit. Metab. Dis. 2008, 31, 151-163. [CrossRef] [PubMed]

134. Helsel, M.E.; Franz, K.J. Pharmacological activity of metal binding agents that alter copper bioavailability. Dalton Trans. 2015, 44, 8760-8770. [CrossRef] [PubMed]

135. Santini, C.; Pellei, M.; Gandin, V.; Porchia, M.; Tisato, F.; Marzano, C. Advances in copper complexes as anticancer agents. Chem. Rev. 2014, 114, 815-862. [CrossRef]

136. Robert, A.; Liu, Y.; Nguyen, M.; Meunier, B. Regulation of copper and iron homeostasis by metal chelators: A possible chemotherapy for Alzheimer's disease. ACC Chem. Res. 2015, 48, 1332-1339. [CrossRef]

137. Akam, E.A.; Chang, T.M.; Astashkin, A.V.; Tomat, E. Intracellular reduction/activation of a disulfide switch in thiosemicarbazone iron chelators. Metallomics 2014, 6, 1905-1912. [CrossRef]

138. Akam, E.A.; Tomat, E. Targeting iron in colon cancer via glycoconjugation of thiosemicarbazone prochelators. Bioconjug Chem. 2016, 27, 1807-1812. [CrossRef]

(C) 2019 by the authors. Licensee MDPI, Basel, Switzerland. This article is an open access article distributed under the terms and conditions of the Creative Commons Attribution (CC BY) license (http://creativecommons.org/licenses/by/4.0/). 